\title{
Phytotoxic effects sewage water on growth, yield, physiological, biochemical and anatomical parameters of faba bean (Vicia faba $\mathrm{L}$.)
}

\author{
Samira A.F. El-Okkiah \\ Agricultural Botany Department, Faculty of Agriculture, Kafrelsheikh University \\ Corresponding author: samira.fouad44@gmail.com
}

\begin{abstract}
Two pot experiments were conducted under greenhouse conditions to study the effect of sewage water on growth, leaves pigments, certain biochemical composition, yield and anatomical of faba bean plants. These experiments were performed in the Department of Agricultural Botany, Faculty of Agriculture, Kafrelsheikh University, during two successive seasons of 2013/2014 and 2014/2015. Faba bean (V. faba L.; cv. Sakha 1) was obtained from Food Legumes Research Section at Sakha Agriculture Research Station (SARS). The experiments were arranged in a factorial arrangement, with three levels of sewage water were diluted with tap water to give 25 , 50 and $100 \%$ in addition to $0 \%$ used in irrigation. The main obtained results will be summarized as follows sewage water at $25 \%$ concentration significantly increased plant height, number of branches/plant, leaf area, dry weights of root and shoot while sewage water at $100 \%$ concentration significantly decreased the same characteristics at 60 and 75 days after sowing in both seasons compared with control plants. Maximum total number of flowers/plant was resulted from low concentration of sewage water $(25 \% \mathrm{Sw})$. There are increases on the number of flowers at all days of flowering period after sowing compared with control plants in both seasons. There was a decrease for total number of flowers/plant from using $(50 \% \mathrm{Sw})$ and $(100 \% \mathrm{Sw})$. Application of sewage water in faba bean plants with low $(25 \% \mathrm{Sw})$ concentration significantly increased number of pods/plant, number of seeds/pod, weight of 100 seeds g., and seed yield g /plant compared with control plants. While the highest concentration of sewage water $(100 \% \mathrm{SW})$ significantly decreased above mentioned characters compared with control plants in both seasons. The treatment of sewage water ( $\mathrm{Sw} 25 \%$ ) significantly increased chl.a, chl. b, and total chl. compared with control plants. Chlorophyll pigment of faba bean leaves were decreased as sewage water concentration increased $(100 \% \mathrm{Sw})$. Data also showed N, P and K percentages significantly increased in shoot under lower concentration of sewage water ( $\mathrm{Sw} 25 \%$ ) irrigation, while $\mathrm{Zn}$ and Fe concentration significantly decreased in shoot in both seasons compared with control plants. The highest concentration of (100\% SW) gave significant decrease for N, P and K percentages in faba bean shoot, in the same time, this treatment caused significant increase for $\mathrm{Zn}$ and $\mathrm{Fe}$ percentages comparing to control plants. Heavy metals $(\mathrm{Cd}$ and $\mathrm{Pb}$ ) in faba bean plant organs (root, shoot and seeds) significantly increased as increasing heavy metals concentration in sewage water content of heavy metals $(\mathrm{Cd}$ and $\mathrm{Pb}$ ) was found in root followed by shoot and seeds. Using sewage water in irrigation faba bean plants at $25 \%$ and $50 \%$ concentration significantly increased protein and total carbohydrates content in seed in both seasons compared with control plants. Application of sewage water in at $100 \%$ concentration significantly decreased seed content of protein and total carbohydrates in both seasons compared with control plants. Anatomical characteristics measurements of faba bean root and stem were affected by all concentration of sewage water irrigation, sewage water at $100 \%$ gave the lowest values of diameter thickness of cortex tissue, diameter of xylem vessel, and these decreases were significant compared with the control. Analysis of fluorescence revealed lignin deposit in the Epidermis cells that was observed in the treatment exposed to the highest level of sewage water. abaxial epidermis of faba bean leaves showed slightly elongated cells irregular in shape with reduced size at the higher concentrations of sewage water treatment.
\end{abstract}

Key wards: Sewage water, Faba bean, Growth, anatomical, Heavy metals, Yield

\section{Introduction}

Environmental stress is a primary cause of crop loss worldwide, resulting an average yield losses of more than $50 \%$ for major crops every year (Brya et al., 2000) and (Chaves and oliveira, 2004) Water pollution is a very important environmental problem and has been drawing considerable public attention over the last few decades. The unscientific disposal of untreated or undertreated sewage, agricultural and industrial effluents results in the accumulation of heavy metals (HMs) in land and water bodies (Purakayastha and Chhonkar, 2010). HMs have a significant toxic effect on human, animals, microorganisms and plants (Majid et al., 2012).In many areas of developing countries, untreated wastewater flows through channels 
into rivers where it is diverted by subsistence farmers to small plots of vegetables and salad crops, grown for nearby urban markets. Such vegetables include carrots, lettuce, cabbage and others which are easily consumed raw as salad. The public health risks of using such contaminated streams for irrigation are obvious (Mead and Griffin, 1998; FAO/WHO, 2004).

Sewage water showed stimulatory as well as inhibitory effects on nitrogen fixing parameters like nodule number, nodule fresh-weight, shoot and root dry weight, and plant $\mathrm{N}$ and $\mathrm{P}$ contents. A significant negative correlation of plant biomass of pea with $\mathrm{Ni}$ shows the phytotoxic effect of $\mathrm{Ni}$ on pea as also reported by (Simon 2000) where pea plants were poorly supplied by nitrogen and growth was limited in the Ni polluted soils.

(Jadoon et al. 2013) studied the effect of irrigation using waste waters released from different industries on the vegetables grown in the vicinity of Faisalabad, Pakistan. The study showed that the waste water released from the textile, ghee and various industries contained heavy metals that accumulated in vegetables and had negative impacts on the vegetables grown. Heavy metals such as $\mathrm{Ni}, \mathrm{Cr}, \mathrm{Zn}, \mathrm{Cd}, \mathrm{As}$ and $\mathrm{Pb}$ resulted in inhibition of root growth, reduced plant growth and yield due to less uptake of water and nutrients (Narain et al. 2012) reported the impact of different concentrations $(10 \%, 25 \%, 50 \%, 75 \%$ and $100 \%$ ) of distillery effluent on chlorophyll and carotenoid contents of Cicer arietinum. The chlorophyll contents showed a gradual decline with the increase in the effluent concentration. (Raia and Khan. 2010) studied the effect of different concentration of industrial effluents containing $\mathrm{Fe}, \mathrm{Cu}, \mathrm{Zn}$, and $\mathrm{Mn}$ on seed germination and seedling growth of Hordeum vulgare L. (Barley). It was observed that the accumulation of these pollutants occurred in the edible part of plants and through food chain these pollutants reached the consumers and caused several harmful effects. A few studies are carried out to date to investigate the impact of heavy metals on one or a few anatomical parameters of the plant (Panou-Filotheou and Bosabalidis, 2004 and Kasim, 2006). Moreover, the understanding of the influence of toxic elements on root anatomy and element distribution is still limited (Vaculik et al., 2012).

(Vicia faba L.), is one of the most important winter crops of high nutritive value in the world as well as in Egypt. Mature seeds of faba bean are good sources of protein (about $25 \%$ in dried seeds), starch, cellulose, vitamin $\mathrm{C}$ and minerals. High yield, smaller seeds, less anti-nutritional factors, high adaptation ability to modern agriculture, the longevity of storage life, ease of transportation and their low cost make this plant more attractive for farmers, feed and food manufactures (Duc, 1997). Due to these benefits including the high nutritional value and energy producing property of this plant and the urgent need to improve its yield and vegetation, this investigation aims to study the effect of different rate sewage on flowering, yield and yield component of broad bean (Vicia faba L.) plants.

The aim of this study the effect of sewage water on growth analysis, leaves pigments, certain biochemical composition, yield and anatomical of faba bean plants.

\section{Materials and methods}

\section{Plant materials and growth conditions}

Two pot experiments were conducted under greenhouse conditions to study the effect of sewage water on growth analysis, leaves pigments, certain biochemical composition, yield and anatomical of faba bean plants. This experiment was performed in the Department of Agricultural Botany, Faculty of Agriculture, Kafrelsheikh University, during two successive seasons of 2013/2014 and 2014/2015. Seeds of faba bean ( $V$. faba L.; cv. Sakha 1) were obtained from Food Legumes Research Section at Sakha Agriculture Research Station (SARS). The experiment was arranged in a factorial arrangement, with four levels of sewage water which diluted with tap water to give $0,25,50$ and $100 \%$ used in irrigation. Plastic pots with a diameter of $25 \mathrm{~cm}$ and a depth of $30 \mathrm{~cm}$ were filled with clay soil. The soil used in this experiment was fertilized with calcium super phosphate fertilizer $\left(\mathrm{P}_{2} \mathrm{O}_{5} 15.5 \%\right)$ added at the rate of $240 \mathrm{~kg} / \mathrm{ha}$ before planting. Potassium was not added because the Egyptian soil is rich in this element. In each pot six seeds were planted on $15^{\text {th }}$ of November 2013/2014 and on $17^{\text {th }}$ of November $2014 / 2015$ seasons. Each pot was inoculated with $10 \mathrm{ml}$ liquid culture of Rhizobium leguminosarum. Containing $6.4 \times 10^{-7}$ cell ml-1were added directly on the seeds (Gomaa, 1989) and then covered with thin layer of the soil. One week after germination the seedlings were thinned to three plants per pot.

\section{Growth and yield parameters Growth parameters}

The following vegetative growth parameters were recorded at two times (60 and 75 days) after sowing date, plant height (stem length was measured from the soil surface to the top of the main stem), number of lateral branches per plant, number of leaves per plant. ,. Leaf area $(\mathrm{cm} 2)$ per plant, measured by using leaf area meter (model 3100), and dry weights of shoot and root per faba bean plant (g): Plant organs were divided into shoot and root, plant organs were oven dried at $70^{\circ} \mathrm{C}$ till constant weight.

\section{Nodule activity}


A set of five healthy and vigorous plants at 45 and 60 days after sowing date for nodulation potential (number of nodules, nodule fresh weight and nodule dry weight). The roots were brought into the laboratory, followed by washing of roots under running water with a screen underneath to catch the detached nodules. The nodules were separated from the roots, counted and stored dried in a desiccator for recording total number of nodules, nodules fresh weight and nodules dry weight per plant was recorded. Care was taken to avoid damage to nodules.

\section{Flowering, Yield and yield components characteristics:}

During blooming stage (at 45days after sowing) two plants were marked at random in each pot. The following characters were recorded per marked plant (included main stem and lateral branches). Flowers number and flowers settings were counted during flowering stage with four days intervals beginning at blooming of the first flower until the end of the blooming stage. At 180days form sowing the number of pods / plant, and number of seeds per plant were recorded. Seed yield per plant $(\mathrm{g})$ : seed weight per plant at about 10-12 percent moisture content. As well as weight of 100 were recorded.

\section{Biochemical studies \\ Chlorophyll pigments concentration}

For all treatments under studies. Chlorophyll content (chlorophyll a and chlorophyll b) were extracted and estimated from fresh leaves, sample were taken throughout the experimental period 36 and 50 days after sowing. Following the standard method of (Moran 1982). Chlorophyll was extracted by using $\mathrm{N}, \mathrm{N}$-dimethylformamide (DMF), three leaf disks from each plant (one disk diameter $0.9 \mathrm{~cm}$ ) were blended with $5 \mathrm{ml}$ DMF for $24 \mathrm{hr}$ in darkness at room temperature and absorbance measurements were made with a spectrophotometer, at $664 \mathrm{~nm}$ for chlorophyll a and $647 \mathrm{~nm}$ for chlorophyll $\mathrm{b}$. The data obtained after the spectrophotometric determination, was mathematically processed using formulae proposed by (Moran 1982).

\section{Chemical composition of plant organs (root, shoot and seeds)}

From each dry matter organ $(0.2 \mathrm{~g})$ was digested in concentrated $\mathrm{H}_{2} \mathrm{SO}_{4}$ on heating block at $180^{\circ} \mathrm{C}$ until the remaining solution appeared clear. One $\mathrm{ml}$ of $\mathrm{H}_{2} \mathrm{O}_{2}$ was added to solution and heating continued to $120^{\circ} \mathrm{C}$ until effervescence stopped from the decolorized digests .The mixture was made up to $50 \mathrm{ml}$ with distilled water. Total nitrogen $\%$ in faba bean plant organs was determined by using micro-Kjeldahl method outlined in the A.OA.C. (1995) and Phosphorus (\%) total phosphorus \% was determined by ascorbic acid method using the colorimetric method that described by John (1970)., and Potassium (\%)content in faba bean plant organs samples were estimated using flame photometer as described by Person (1976).

Micronutrients concentration: Determination of $\mathrm{Fe}$ or $\mathrm{Zn}$ element in acid digest solution of the samples was carried by the aid of atomic absorption spectrophotometer according to Chapman and Pratt, 1982

Heavy metals $(\mathbf{C d \& P b})$ were measured in the digest acid solution of the samples by the aid of atomic absorption spectrophotometer according to (Chapman and Pratt, 1982.)

Protein concentration of the seeds: Total nitrogen percentage of faba bean seeds was determined by micro- Kjeldahl method as described by (A.O.A.C. 1995). While the percentage of protein in the seeds was calculated by multiplying total $\mathrm{N} \%$ by factor 6.25 .

Total Carbohydrates in seeds: Total soluble carbohydrates (TSC) were determined according to (Yemm and Willis 1954).

\section{Anatomical studies:}

\section{Samples were also observed by light microscope}

After 45 days from sowing a minimum of 5 samples of root and stem of faba bean plant were taken at random (Specimens $1 \mathrm{~cm}$ long was taken from the fourth upper internode and concerning the roots $(1 \mathrm{~cm})$ samples from the sub apical part of primary root tip were cut.). The sampled material was fixed in FAA (50 $\%$ ethanol $+5 \%$ formaldehyde $+10 \%$ glacial acetic acid in water) for $48 \mathrm{~h}$ Samples were washed twice in $70 \%$ ethyl alcohol. Dehydration was done by passing the samples in a series of the following ethyl alcohol concentrations (75-100\%) each samples were passed through out of mixture of xylol and absolute ethyl alcohol in the following percentage $25 \%, 50 \%$ and $75 \%$ and pure xylol in at lastly two changes for four each dilution. Paraffin shavings reagent containing samples until saturation within 12 hours, two changes of Paraffin were done to get rid of all traces of xylol. Samples were taken embedded in melted Paraffin in embedding paper trays, and then cooled rapidly with cold water. Sections (10-12 microns thick) were done with Rotary Microtome (Leica RM 2125 apparatus), Paraffin sections were a fixed to the slides with Albumin. Slides were left to complete dryness for 24 hours on dry oven at $50^{\circ} \mathrm{C}$.Before staining the slides were placed in two changes of xylol for about 10 times, and then transferred to a jar containing equal parts of absolute ethyl alcohol and xylol for 5 minutes. 
The sections were plunged in close series of descending dilution ${ }^{\mathrm{s}}$ of ethyl alcohol ranged from absolute to $5 \%$ for 5 minutes. Then Sections were stained for 10 minutes in a jar containing $1 \%$ Safranin, and then the excess stain was washed. Sections were stained for 1 minute in a jar containing 1\%light green, Sections were then cleared in xylol and mounted in Canda Balsam and prepared for microscopic examination (Ruzin 1999). Five reading for each slide were examined with electric microscope (Leica DM LS) with digital camera (Leica DC300), then photographed.
Series of hand sections of roots were prepared at $1 \mathrm{~mm}$ intervals from the fourth upper internode For suberin visualization in fluorescence microscopy, the free hand sections were stained by $0.01 \%$ Fluorol yellow 088 dissolved in lactic acid for $30 \mathrm{~min}$ and washed in distilled water according to (Lux et al. 2005). The samples were placed into a drop of $0.1 \%$ $\mathrm{FeCl}_{3}$ dissolved in $50 \%$ glycerin prior to observation. The sections for bright-field observations were stained with toluidine blue. The sections were observed under a Zeiss Axioskop 2 plus epifluorescence microscope and documented by an Olympus DP 72 digital camera.

Samples were also observed by epi-fluorescence.

Table 1. Physical and chemical properties of experimental soil wastewater

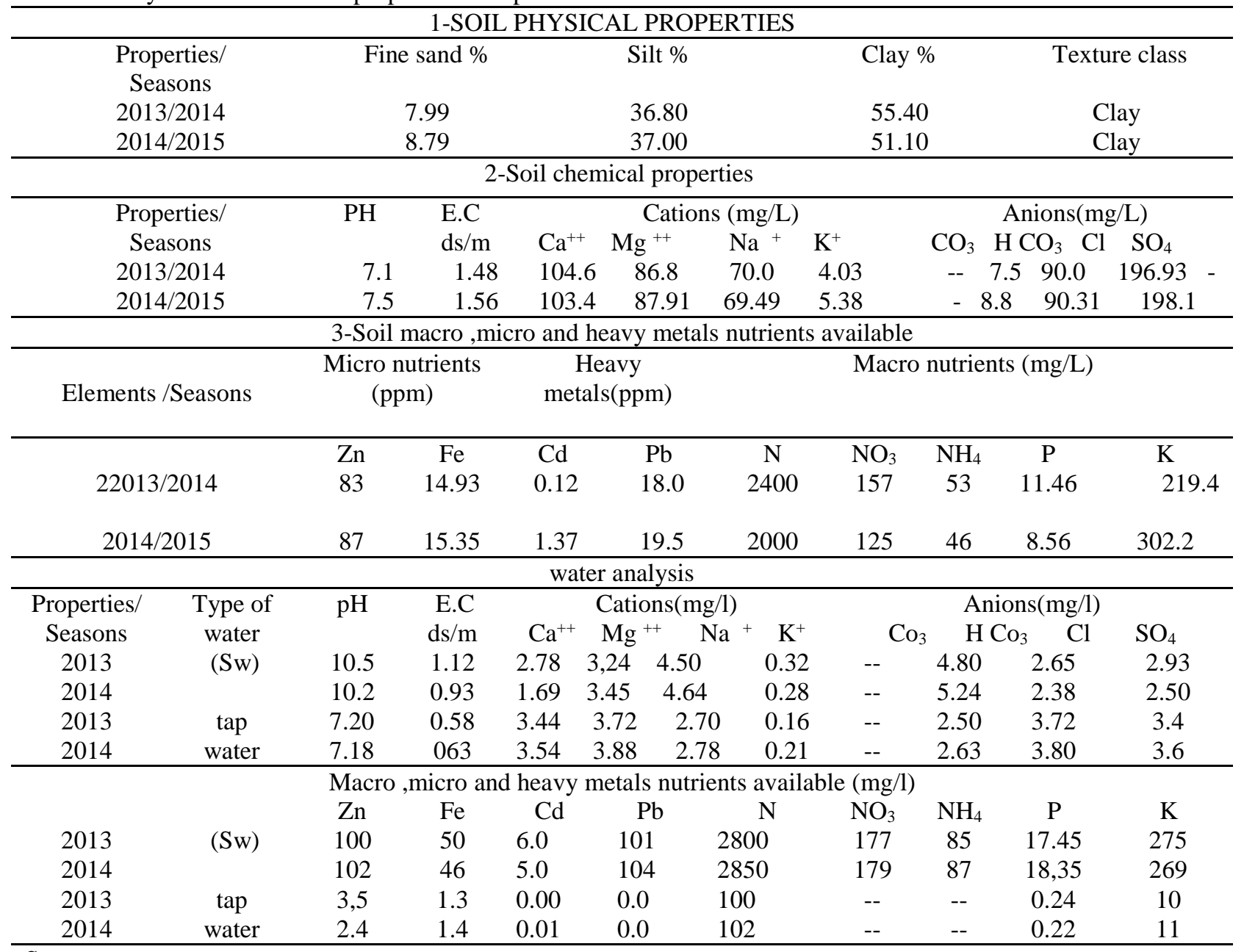

$\mathrm{Sw}=$ sewage water

\section{Leaf stomatal density and guard cell size}

The impression approach was used to determine leaf stomatal density, which was expressed as the number of stomata per unit leaf area (Radoglou and Jarvis, 1992). The abaxial epidermis of the leaf was cleaned first using a degreased cotton ball, and then carefully smeared with nail varnish in the mid-area between the central vein and the leaf edge, for approximately $20 \mathrm{~min}$. The thin film (approximately 5 $\mathrm{mm} \times 15 \mathrm{~mm}$ ) was peeled off from the leaf surface, mounted on a glass slide, immediately covered with a cover slip, and then lightly pressured with fine-point 
tweezers. Numbers of stomata (s) and epidermal cells (e) for each film strip were counted under a photomicroscope system with computer attachment (MPS 60, Leica, Wetzlar, Germany). Impressions were taken from the six youngest, fully expanded leaves for each treatment

\section{Soil and sewage water properties}

Soil samples were taken from the major root zone before faba bean seeds were planted and at the end of the two growing seasons. The soil samples air-dried, crushed, passed through a $2 \mathrm{~mm}$ sieve and were analyzed for various physicochemical properties. Each sample was prepared to form soil texture and using the hydrometer method according to Bouyoucos (1965). Soil $\mathrm{pH}$ and Electrical Conductivity (EC) were determined in 1: 2 soil: water suspension by $\mathrm{pH}$ and EC meters (Hati et al., 2007). Calcium carbonate $\left(\mathrm{CaCO}_{3}\right)$ was measured with a calcimeter. Heavy Metals ( $\mathrm{Pb}$ and $\mathrm{Cd}$ ) soil content was extracted after digestion with 3:1 concentrated $\left(\mathrm{HC} 1-\mathrm{HNO}_{3}\right)$ and measured by Atomic Absorption Spectrophotometer (Gasco and Lobo, 2007). The water samples were brought to the laboratory in resistant plastic bottles to avoid adherence to the container wall. Water samples were filtered through $42 \mathrm{~mm}$ filter paper and stored at $4{ }^{\circ} \mathrm{C}$ to minimize microbial decomposition of solids (Yadav et al., 2002; Bhati and Singh, 2003). Some parameters were measured separately, $\mathrm{pH}$ and EC by the procedure described using OMA (1990) and heavy metals $(\mathrm{Pb}$ and $\mathrm{Cd})$ of water samples were estimated by the aqua regia method of Jackson (1973) followed by a measurement of concentrations using an Atomic Absorption Spectrophotometer (AAS).

\section{Statistical analysis of the data}

The data were statistically analyzed using the oneway analysis of variance as described by (Snedecor and Cochran 1967). The means were compared by LSD using SPSS version

\section{Results and discussion}

\section{Growth and Yield parameters}

Results showed that, growth characteristics were significantly affected with sewage water treatments (Tables 2 and 3). The results indicate that sewage water at $25 \%$ and $50 \%$ concentrations significantly increased plant height at 60 days after sowing compared with control plants in both seasons. While sewage water at $50 \%$ concentration significantly decreased plant height at 75 days after sowing compared with control plants. Data also showed that $100 \%$ concentration of sewage water significantly decreased plant height at two stages compared with control plants. Data also in Table (2 and 3) showed that, there was a remarkable significant increase in leaf area of faba bean plants obtained from using $25 \%$ sewage water at two stages compared with control plants in both seasons. Otherwise sewage water at $100 \%$ gave a significant decrease in leaf area of faba bean plants at two stages compared with the plants under control conditions in both seasons. Data in Table (2) indicate that $50 \% \mathrm{SW}$ had no significant decrease in leaf area of faba bean plants at 60 days after sowing compared with control plants in both seasons. While the same treatment gave significant decrease in leaf area of faba bean plants at 75 days after sowing compared with control plants in both seasons. Data also showed that there was a remarkable significant increase in number of branches/plant obtained from using $25 \% \mathrm{SW}$ at two stages compared with the plants under control conditions in both seasons.

Table 2. Effect of sewage water irrigation on faba bean plant height, , leaf area, number of branches/plant, root and shoot dry weight at 60 days after sowing during 2013/2014 and 2014/2015 growing seasons

\begin{tabular}{ccccccccccc}
\hline \multirow{2}{*}{$\begin{array}{c}\text { Water } \\
\text { irrigation }\end{array}$} & $\begin{array}{c}\text { Plant height } \\
(\mathbf{c m})\end{array}$ & \multicolumn{2}{c}{$\begin{array}{c}\text { Leaf area / plant } \\
\left(\mathrm{cm}^{2}\right)\end{array}$} & \multicolumn{2}{c}{$\begin{array}{c}\text { No. of } \\
\text { branches/plant }\end{array}$} & \multicolumn{2}{c}{$\begin{array}{c}\text { Root dry } \\
\text { weight }(\mathrm{g})\end{array}$} & \multicolumn{2}{c}{$\begin{array}{c}\text { shoot dry } \\
\text { weight }(\mathrm{g})\end{array}$} \\
\cline { 2 - 11 } & $\mathbf{2 0 1 3}$ & $\mathbf{2 0 1 4}$ & $\mathbf{2 0 1 3}$ & $\mathbf{2 0 1 4}$ & $\mathbf{2 0 1 3}$ & $\mathbf{2 0 1 4}$ & $\mathbf{2 0 1 3}$ & $\mathbf{2 0 1 4}$ & $\mathbf{2 0 1 3}$ & $\mathbf{2 0 1 4}$ \\
\hline control & $\mathbf{3 5 . 3}$ & $\mathbf{3 6 . 7}$ & $\mathbf{3 9 4 . 8}$ & $\mathbf{3 8 5 . 7}$ & 1.33 & 1.3 & $\mathbf{1 . 7 3}$ & $\mathbf{2 . 2}$ & $\mathbf{9 . 2}$ & $\mathbf{9 . 7}$ \\
Sw25\% & $\mathbf{4 3 . 5}$ & $\mathbf{4 5 . 0}$ & $\mathbf{4 5 7 . 3}$ & $\mathbf{4 5 9 . 2}$ & $\mathbf{3 . 3 3}$ & $\mathbf{3 . 7}$ & $\mathbf{2 . 3 0}$ & $\mathbf{2 . 3}$ & $\mathbf{1 1 . 2}$ & $\mathbf{1 1 . 8}$ \\
Sw50\% & $\mathbf{4 2 . 7}$ & $\mathbf{4 3 . 0}$ & $\mathbf{3 4 4 . 9}$ & $\mathbf{3 5 4 . 9}$ & $\mathbf{0 . 6 7}$ & $\mathbf{1 . 3}$ & $\mathbf{1 . 2 6}$ & $\mathbf{1 . 4}$ & $\mathbf{7 . 1}$ & $\mathbf{7 . 0}$ \\
Sw100\% & $\mathbf{3 2 . 3}$ & $\mathbf{3 0 . 0}$ & $\mathbf{2 9 6 . 7}$ & $\mathbf{3 0 2 . 7}$ & $\mathbf{0 . 3 3}$ & $\mathbf{1 . 3}$ & $\mathbf{1 . 1 0}$ & $\mathbf{1 . 5}$ & $\mathbf{5 . 7}$ & $\mathbf{5 . 5}$ \\
LSD0.05 & $\mathbf{2 . 4 9}$ & $\mathbf{1 . 7 8}$ & $\mathbf{2 6 . 5 0}$ & $\mathbf{3 4 . 0 1}$ & $\mathbf{1 . 0 9}$ & $\mathbf{1 . 0 9}$ & $\mathbf{0 . 3 4}$ & $\mathbf{0 . 3 3}$ & $\mathbf{0 . 6 8}$ & $\mathbf{0 . 5 3}$ \\
\hline
\end{tabular}


Table (3) Effect of sewage water irrigation on faba bean plant height, , leaf area number of branches/plant, root and shoot dry weight at 75 days after sowing during 2013/2014 and 2014/2015 growing seasons

\begin{tabular}{|c|c|c|c|c|c|c|c|c|c|c|}
\hline \multirow{2}{*}{$\begin{array}{c}\text { Water } \\
\text { irrigation }\end{array}$} & \multicolumn{2}{|c|}{$\begin{array}{l}\text { Plant height } \\
\text { (cm) }\end{array}$} & \multicolumn{2}{|c|}{$\begin{array}{c}\text { Leaf area / plant } \\
\left(\mathrm{cm}^{2}\right)\end{array}$} & \multicolumn{2}{|c|}{$\begin{array}{c}\text { No. of } \\
\text { branches/plant }\end{array}$} & \multicolumn{2}{|c|}{$\begin{array}{l}\text { Root dry } \\
\text { weight (g) }\end{array}$} & \multicolumn{2}{|c|}{$\begin{array}{l}\text { Shoot dry } \\
\text { weight (g) }\end{array}$} \\
\hline & 2013 & 2014 & 2013 & 2014 & 2013 & 2014 & 2013 & 2014 & 2013 & 2014 \\
\hline control & 62.7 & 57.3 & 894.8 & 885.7 & 2.7 & 3 & 2.5 & 2.8 & 20.2 & 20.8 \\
\hline Sw25\% & 63.5 & 65.0 & 973.8 & 965.9 & 3.7 & 4.3 & 3.3 & 3.5 & 23.4 & 22.9 \\
\hline Sw50\% & 52.7 & 54.0 & 744.9 & 755.0 & 2.3 & 2.7 & 2.1 & 2.4 & 17.8 & 19.3 \\
\hline Sw100\% & 42.3 & 40.0 & 496.7 & 499.6 & 2.0 & 2.0 & 1.9 & 1.9 & 15.1 & 16.7 \\
\hline LSD0.05 & 2.12 & 2.42 & 33.43 & 35.71 & 0.94 & 0.80 & 0.16 & 0.30 & 0.85 & 0.30 \\
\hline
\end{tabular}

Sewage water at $50 \%$ concentration had insignificant increase on number of branches/plant at two stages compared with the plants under control conditions in the $2^{\text {nd }}$ season. While the same treatment gave a significant decrease in number of branches/plant in the $1^{\text {st }}$ season at 60 days after sowing. The results were obtained from using $100 \%$ SW show that there was insignificant increase or decrease in number of branches compared with control plants in the $2^{\text {nd }}$ season at 60 days after sowing compared with control plants. While the same treatment gave a significant decrease in number of branches/plant at 75 days after sowing date compared with control plant in both seasons. Data also in Table (2 and 3 ) showed that sewage water at $25 \%$ concentration significantly increased dry weight of root and shoot at two stages compared with control plants in both seasons. While sewage water at $100 \%$ concentration had a significant decrease in dry weight of root and shoot at two stages compared with control plants in both seasons. This increase in the vegetative growth parameters of faba bean plants especially at the lowest concentration $(25 \%$ and $50 \% \mathrm{SW})$ may due to the increasing content of nutrients in soil irrigated with wastewater these results are in agreement with those obtained by Tawfik, (2008) reported that highest growth (fresh and dry weights) of Vicia faba, (Giza 461) was recorded for plants irrigated from irrigation canal contaminated with sewage sludge followed by plants irrigated with industrial drain as determined for 30, 60 and 90 days as age plants On other hand at the higher concentration of sewage water irrigation results in a slightly inhibitory effect on growth may due to the sewage water have contain heavy metal like $\mathrm{Cd}$ (Ehiagbonare et al., 2011). In alfalfa (Medicago sativa) the authors' mentioned that $5 \mathrm{ppm}$ of $\mathrm{Cd}$ reduced shoot size by $16 \%$ compared to the control.

Fig. (1\&2) showed that, total number of flowers/plant was increased by sewage water at low concentration $(25 \%)$ compared with the control plants in both seasons. While there was decrease in number of flowers/plant obtained from using sewage water at 50 $\%$ and $100 \%$ concentration. The highest reduction was obtained from using sewage water at $100 \%$ concentration the all stages compared with control in both seasons.

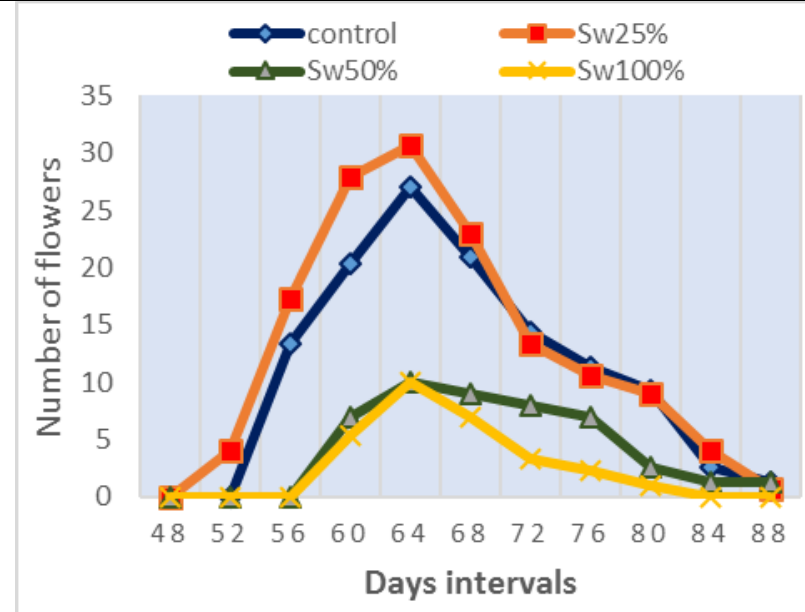

Fig. (1) effect of sewage water irrigation, on total number of flowers during 2013/2014

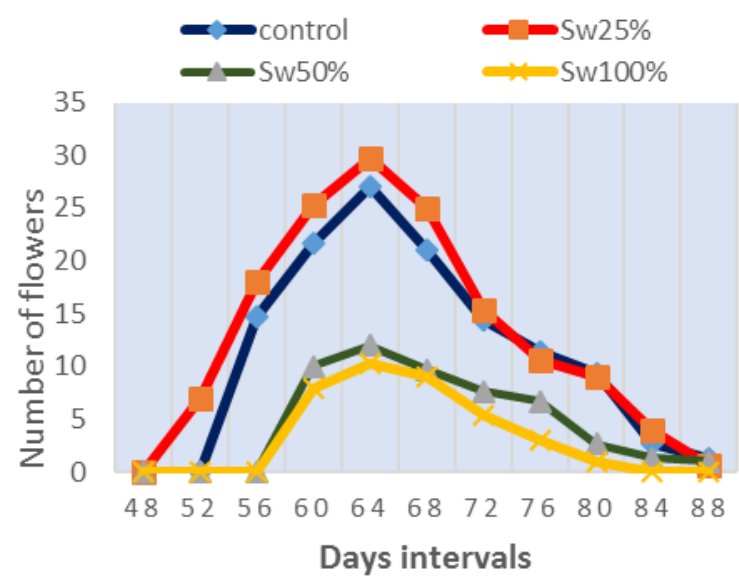

Fig. (2) effect of sewage water irrigation, on total number of flowers during $2014 / 2015$ 
Fig. (3\&4) Showed a high significant difference was detected among the treatments. The highest value setting flower/plant of faba bean was found in the plants watered with (Sw25\%) This increase was at all days with the control plants in both seasons. On the other hand, there was decrease in number setting flower/plant obtained from using sewage water at the highest two levels. The lowest total number setting flower/plant was found in the plants watered with $100 \%$ concentration compared with control both seasons .This reduction may be due to decreasing number of branches and photosynthetic pigment content (El-Okkiah, Samira 2010)

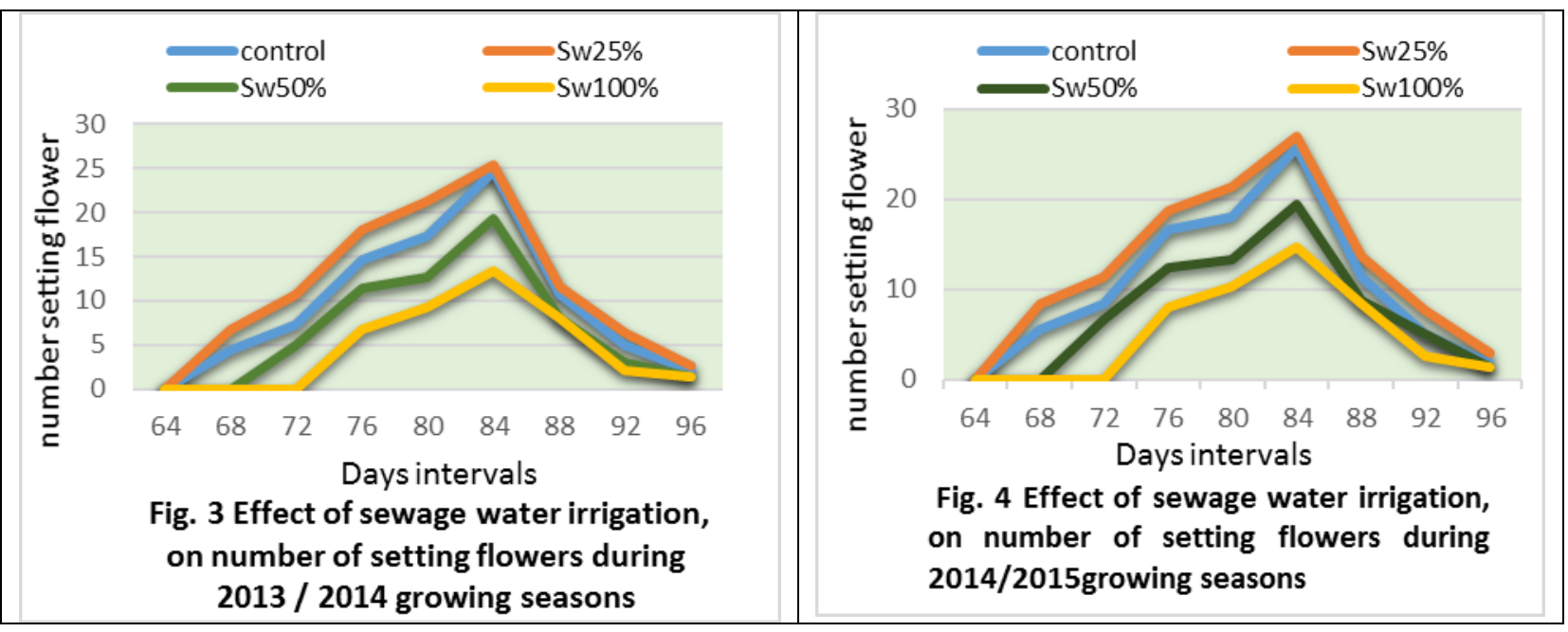

Data in Table (4) showed that sewage water application at lower concentration (25\%) significantly increased number of pods / plant compared to the control plants in both seasons. The increase in number of pods / plant in this treatment may be due to the increase in number of branches/plant and/or the increase in number of flowers and pods/branches. The results also showed significant increase in number of seeds / pod, weight of 100 seeds and seed yield / plant and under the same treatment compared with control plants in both seasons. On the other hand sewage water application at the highest concentration (100\%) significantly decreased number of pods / plant, number of seeds / pod, weight of 100 seeds and seed yield / plant in compared with control plants in both seasons. These results are in agreement with those obtained by Aziz et al., (1995) pointed out that the wastewater increased the growth and yield parameters of four wheat cultivars. Irrigation with wastewater leads to increasing in forage qualitative yields about 3 to 35 times more than irrigation with well water (Asgari $\boldsymbol{e t}$ al., 2007).

Table (4) Effect of sewage water irrigation on yield and yield components of faba bean plant during 2013/2014 and 2014/2015 growing seasons

\begin{tabular}{lcccccccc}
\hline \multirow{2}{*}{ Water irrigation } & \multicolumn{2}{c}{ No. of pod/plant } & \multicolumn{2}{c}{ No. of seeds/pod } & \multicolumn{2}{c}{ weight of 100seeds $($ g) } & \multicolumn{2}{c}{ seed yield / plant $(\mathrm{g})$} \\
\cline { 2 - 9 } & 2013 & 2014 & 2013 & 2014 & 2013 & 2014 & 2013 & 2014 \\
\hline control & 19.333 & 20.667 & 3.33 & 4 & 66 & 69.67 & 58 & 60 \\
Sw25\% & 21 & 23.333 & 4.67 & 5.33 & 70.67 & 74 & 64 & 65.67 \\
Sw50\% & 17 & 18.667 & 2.67 & 3.33 & 60.33 & 60.33 & 46.667 & 47.67 \\
Sw100\% & 12.333 & 13.667 & 2 & 2.33 & 54 & 54.33 & 38.667 & 40.33 \\
LSD 0.05 & 1.803 & 2.369 & 0.941 & $\mathbf{0 . 9 4 1}$ & $\mathbf{2 . 4 3 1}$ & $\mathbf{2 . 3 0 6}$ & 4.175 & 3.122 \\
\hline
\end{tabular}

\section{Nodule activity}

Data in Table (5) and Fig. (5), demonstrated that sewage water showed stimulatory as well as inhibitory effects on nitrogen fixing parameters like nodule number, nodule fresh-weight and dry weight. Nodule numbers and nodule fresh-weight and dry weight per plant were significantly improved by sewage water at level $25 \%$ the highest nodule number and nodule fresh-weight and dry weight obtained by sewage water at level $25 \%$ compared with control at 60 days after sowing . Asignificant inhibition of nodulation was caused by sewage water at level $100 \%$. These results 
confirmed with Abd-Alla et al., (1999) they founed at an application level of 30 (w/w) sewage sludge compared with control, nodulation was increased by 55 $\%, 96 \%$ and $171 \%$ for faba bean, soy bean and lupin respectively. Conversely at high application rates (40 and $50 \%$ ) sewage sludge significantly inhibited nodulation.

Table 5 Effect of sewage water irrigation, on nodulation of faba bean during 2013/2014 and 2014/2015 growing seasons

\begin{tabular}{ccccccccc}
\hline \multirow{2}{*}{$\begin{array}{c}\text { Water } \\
\text { irrigation }\end{array}$} & \multicolumn{2}{c}{$\begin{array}{c}\text { Nodule number } \\
\text { (NN)after45 day }\end{array}$} & \multicolumn{2}{c}{$\begin{array}{c}\text { Nodule number } \\
\text { (NN)after60 day }\end{array}$} & \multicolumn{2}{c}{$\begin{array}{c}\text { Nodule fresh matter } \\
\text { (NFM)45 (g) }\end{array}$} & \multicolumn{2}{c}{$\begin{array}{c}\text { Nodule fresh matter } \\
\text { (NFM)60 (g) }\end{array}$} \\
\cline { 2 - 9 } & $2013 / 2014$ & $2014 / 2015$ & $2013 / 2014$ & $\mathbf{2 0 1 4}$ & $\mathbf{2 0 1 3}$ & $\mathbf{2 0 1 4}$ & $\mathbf{2 0 1 3}$ & $\mathbf{2 0 1 4}$ \\
\hline control & $\mathbf{9 5 . 3 3}$ & $\mathbf{9 9 . 0 0}$ & $\mathbf{7 5 . 6 7}$ & $\mathbf{7 5 . 6 7}$ & $\mathbf{1 . 3 1}$ & $\mathbf{1 . 6 7}$ & $\mathbf{1 . 2 3}$ & $\mathbf{1 . 3 7}$ \\
Sw25\% & $\mathbf{7 6 . 6 7}$ & $\mathbf{7 8 . 6 7}$ & $\mathbf{8 3 . 3 3}$ & $\mathbf{8 9 . 0 0}$ & $\mathbf{1 . 7 2}$ & $\mathbf{2 . 0 9}$ & $\mathbf{1 . 4 3}$ & $\mathbf{1 . 4 9}$ \\
Sw50\% & $\mathbf{6 6 . 3 3}$ & $\mathbf{7 0 . 3 3}$ & $\mathbf{3 4 . 0 0}$ & $\mathbf{3 3 . 3 3}$ & $\mathbf{0 . 6 4}$ & $\mathbf{0 . 7 4}$ & $\mathbf{0 . 8 7}$ & $\mathbf{0 . 9 6}$ \\
Sw100\% & $\mathbf{0 . 0 0}$ & $\mathbf{0 . 0 0}$ & $\mathbf{0 . 0 0}$ & $\mathbf{0 . 0 0}$ & $\mathbf{0 . 0 0}$ & $\mathbf{0 . 0 0}$ & $\mathbf{0 . 0 0}$ & $\mathbf{0 . 0 0}$ \\
LSD0.05 & $\mathbf{4 . 3 1}$ & $\mathbf{4 . 5 8}$ & $\mathbf{4 . 2 8}$ & $\mathbf{2 . 2 4}$ & $\mathbf{0 . 0 5}$ & $\mathbf{0 . 0 5}$ & $\mathbf{0 . 0 4}$ & $\mathbf{0 . 1 6}$ \\
\hline
\end{tabular}
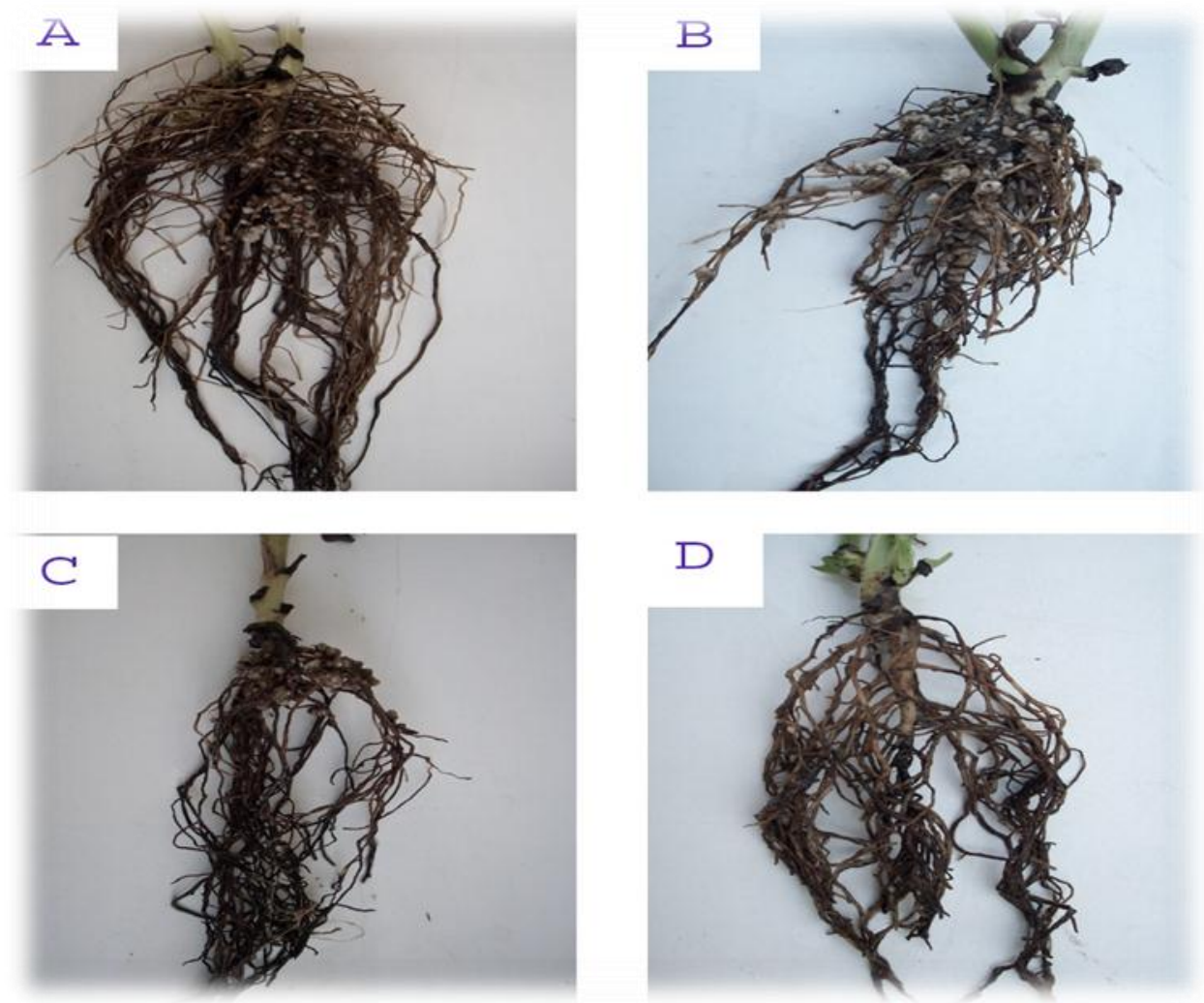

Fig. (5) Effect of sewage water irrigation, on nodulation of faba bean
A- Control
B- $25 \% \mathrm{SW}$
C- $50 \% \mathrm{SW}$
D- $100 \% \mathrm{SW}$

\subsection{Physiological and biochemical characteristics}

3.1.1. Chlorophyll pigments concentration:

Data presented in Table (6) and Fig. (6), showed that chl.a and total chl. of faba bean leaves significantly decreased as application the highest concentration of sewage water $(100 \% \mathrm{SW})$. This reduction in chlorophyll pigment may be attributed to sewage water content $\mathrm{Cd}$ and $\mathrm{Pb}$ which substituted $\mathrm{Mg}$ by $\mathrm{Cd}$ causing denaturation in chlorophyll molecule (kupper et al., 2002). Tewfik, (2008) stated that control plants gave the highest chlorophyll $\mathrm{a}, \mathrm{b}$ and $\mathrm{a}+\mathrm{b}$ followed by plants irrigated from irrigation canal contaminated with sewage sludge. On other hand all parameters (Chl.a, Chl.b and Total Chl.) were significantly increased by sewage water irrigation $(25 \% \mathrm{SW})$ compared to the control treatment in both seasons. The increases in chlorophyll parameters were attributed to the increase 
in organic matter and $\mathrm{Fe}$ ions in the soil. Saravanamoorthy and Ranjitha Kumari, (2007) in peanut pointed out that Textile waste water application increased chlorophyll a and b and total chlorophyll content.

Table 6. Effect of sewage water irrigation on Chlorophyll pigments concentrationof faba bean during 2013/2014 and 2014/2015 growing seasons

\begin{tabular}{|c|c|c|c|c|c|c|}
\hline $\begin{array}{c}\text { Water } \\
\text { irrigation }\end{array}$ & $\begin{array}{c}\text { Chl a } \\
\left(\mathbf{M g} / \mathbf{d m}^{2}\right)\end{array}$ & $\begin{array}{c}\text { Chl a } \\
\left(\mathrm{Mg} / \mathbf{d m}^{2}\right)\end{array}$ & $\begin{array}{c}\text { Chl b } \\
\left(\mathrm{Mg} / \mathbf{d m}^{2}\right)\end{array}$ & $\begin{array}{c}\text { Chl b } \\
\left(\mathrm{Mg} / \mathbf{d m}^{2}\right)\end{array}$ & $\begin{array}{l}\text { Total chl } \\
\left(\mathbf{M g} / \mathbf{d m}^{2}\right.\end{array}$ & $\begin{array}{r}\text { Total chl } \\
\left(\mathbf{M g} / \mathbf{d m}^{2}\right)\end{array}$ \\
\hline & 2013 & 2014 & 2013 & 2014 & 2013 & 2014 \\
\hline Control & 7.89 & 8.04 & 1.93 & 2.15 & 9.83 & 10.19 \\
\hline Sw25\% & 9.22 & 9.33 & 2.48 & 2.80 & 11.70 & 12.13 \\
\hline Sw50\% & 6.85 & 7.22 & 2.37 & 2.48 & 9.21 & 9.70 \\
\hline Sw100\% & 6.40 & 6.34 & 2.66 & 2.59 & 9.07 & 8.92 \\
\hline LSD0.05 & 0.46 & 0.19 & 0.20 & 0.43 & 0.60 & 0.42 \\
\hline
\end{tabular}

3.1.2. Plant nutrient elements concentration

Data in Table (7) showed that sewage water application at lower concentration $(25 \% \mathrm{SW})$ had insignificant increased in nitrogen percentage in root of faba bean plant while the same treatment gave significant increase of Nitrogen percentage in shoot in both seasons compared with control. On the other hand, the highest application of sewage water $(100 \%$ SW) gave significant decrease for nitrogen percentage in root and shoot of faba bean plant in both seasons. These results confirmed with Kiziloglu et al. (2007) who showed that wastewater irrigation treatment increased $\mathrm{N}$ contents of cauliflower and red cabbage plants.

Data also showed that sewage water at $25 \%$ significantly increased phosphorus percentage in shoot in both seasons compared with control. While the same treatment led to insignificant increase phosphorus percentage in root in the $1^{\text {st }}$ season. Data also showed that there was insignificant decrease in phosphorus percentage in root and shoot by using sewage water at $50 \%$ in both seasons. In the same time the highest application of sewage water $(100 \%$ SW) gave a significant decrease for phosphorus percentage in shoot in both seasons. Data in Table (7) showed that sewage water application at $25 \%$ significantly increased $\mathrm{K}$ percentages in root and shoot compared with control in both seasons. Data presented in Table (7) showed that sewage water application at $50 \%$ significantly increased $\mathrm{K}$ percentages in root in the $2^{\text {nd }}$ seasons. On other hand the highest application of sewage water $(100 \% \mathrm{SW})$ gave a significant decrease on $\mathrm{K}$ percentage in root and shoot of faba bean plants in both seasons. These results confirmed with Eid and Shereif (1996) who reported that irrigation of some crops (Vicia faba, Hordeum vulgar and Brassica napus) with wastewater (mixed with fresh water 1:6) increased $\mathrm{P}$ and $\mathrm{K}$ content significantly compared with fresh water.

Table 7. Effect of sewage water irrigation on nitrogen, phosphor and potassium percentage, of faba bean plant organs during 2013 and 2014 growing seasons

\begin{tabular}{ccccccccccccc}
\hline Water & \multicolumn{2}{c}{ Root N\% } & \multicolumn{2}{c}{ shoot N\% } & \multicolumn{2}{c}{ Root P\% } & \multicolumn{2}{c}{ shoot P\% } & \multicolumn{2}{c}{ Root K\% } & \multicolumn{2}{c}{ shoot K\% } \\
\cline { 2 - 12 } irrigation & $\mathbf{2 0 1 3}$ & $\mathbf{2 0 1 4}$ & $\mathbf{2 0 1 3}$ & $\mathbf{2 0 1 4}$ & $\mathbf{2 0 1 3}$ & $\mathbf{2 0 1 4}$ & $\mathbf{2 0 1 3}$ & $\mathbf{2 0 1 4}$ & $\mathbf{2 0 1 3}$ & $\mathbf{2 0 1 4}$ & $\mathbf{2 0 1 3}$ & $\mathbf{2 0 1 4}$ \\
\hline Control & $\mathbf{2 . 4 4}$ & $\mathbf{2 . 4 6}$ & $\mathbf{3 . 5 2}$ & $\mathbf{3 . 5 2}$ & $\mathbf{0 . 1 9}$ & $\mathbf{0 . 1 9}$ & $\mathbf{0 . 3 7}$ & $\mathbf{0 . 3 9}$ & $\mathbf{0 . 8 4}$ & $\mathbf{0 . 8 8}$ & $\mathbf{2 . 9 8}$ & $\mathbf{2 . 9 3}$ \\
Sw25\% & $\mathbf{2 . 5 5}$ & $\mathbf{2 . 5 9}$ & $\mathbf{3 . 7 9}$ & $\mathbf{3 . 8 6}$ & $\mathbf{0 . 1 9}$ & $\mathbf{0 . 2 0}$ & $\mathbf{0 . 4 8}$ & $\mathbf{0 . 4 9}$ & $\mathbf{1 . 1 5}$ & $\mathbf{1 . 5 4}$ & $\mathbf{3 . 4 7}$ & $\mathbf{3 . 1 0}$ \\
Sw50\% & $\mathbf{2 . 0 7}$ & $\mathbf{2 . 1 4}$ & $\mathbf{3 . 0 5}$ & $\mathbf{3 . 3 3}$ & $\mathbf{0 . 1 8}$ & $\mathbf{0 . 1 8}$ & $\mathbf{0 . 3 6}$ & $\mathbf{0 . 3 8}$ & $\mathbf{0 . 7 9}$ & $\mathbf{1 . 0 4}$ & $\mathbf{2 . 4 6}$ & $\mathbf{2 . 4 3}$ \\
Sw100\% & $\mathbf{1 . 7 7}$ & $\mathbf{1 . 8 8}$ & $\mathbf{2 . 3 9}$ & $\mathbf{2 . 8 5}$ & $\mathbf{0 . 1 8}$ & $\mathbf{0 . 1 8}$ & $\mathbf{0 . 2 9}$ & $\mathbf{0 . 2 7}$ & $\mathbf{0 . 6 9}$ & $\mathbf{0 . 6 6}$ & $\mathbf{2 . 0 2}$ & $\mathbf{2 . 0 2}$ \\
\hline LSD 0.05 & $\mathbf{0 . 1 9 0}$ & $\mathbf{0 . 1 8 0}$ & $\mathbf{0 . 2 1 3}$ & $\mathbf{0 . 1 5 6}$ & $\mathbf{0 . 0 0 5}$ & $\mathbf{0 . 0 0 3 7}$ & $\mathbf{0 . 0 1 9}$ & $\mathbf{0 . 0 0 1}$ & $\mathbf{0 . 0 4 3}$ & $\mathbf{0 . 0 1 3}$ & $\mathbf{0 . 1 7}$ & $\mathbf{0 . 1 2}$ \\
\hline
\end{tabular}

Fig. (7) Showed that sewage water application at $25 \%$ decreased Zinc and iron concentrations in root and shoot compared with control in both seasons. While sewage water at $50 \%$ and $100 \%$ led to increase in Zinc and iron concentrations of root and shoot of faba bean plants compared with control in both seasons. The highest values of Zinc and iron concentrations obtained from using sewage water at
100\%. These results confirmed with Abdel-Sabour and Rabie (2003) revealed that irrigation with different wastewater significantly increased the concentration of heavy metals ( $\mathrm{Zn}$ ) in vegetable plants (spinach, rocket and Jew's mallow) especially the leafy species. Badawy and El- Motaium (2003) found that the concentrations of $\mathrm{Zn}$, in tomato leaves and fruits increased with sewage sludge application rate. 


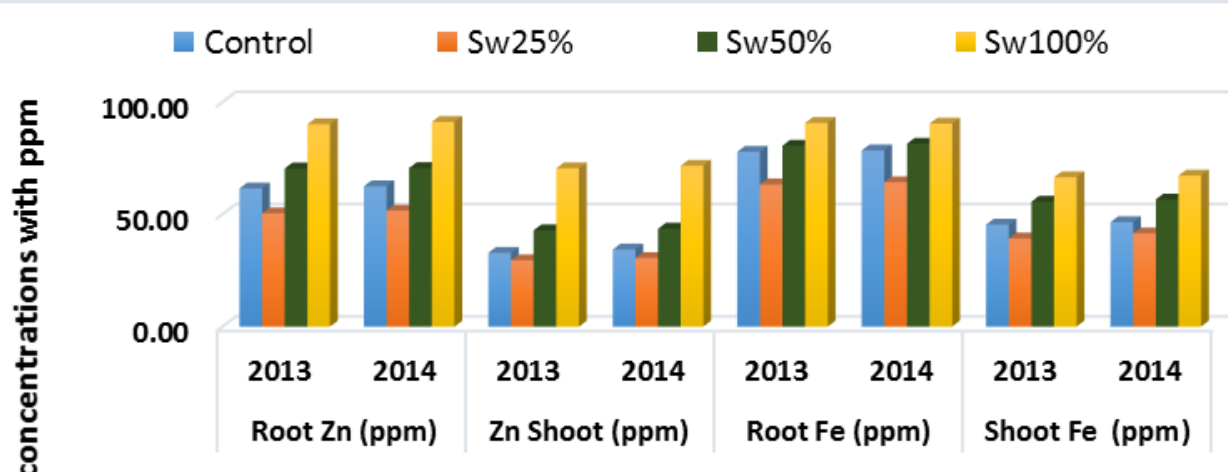

Fig. (7) Effect of sewage water irrigation on Zinc and Iron concentrations, of faba bean plant organs during 2013 and 2014 growing seasons

Fig. (8), showed that, there was a remarkable gradual increase in faba bean plant organs (root and shoot) of heavy metals ( $\mathrm{Cd}$ and $\mathrm{Pb})$ content concentrations with increasing sewage water concentrations. This increasing in heavy metals content may be attributed to increasing of heavy metals $(\mathrm{Cd}$ and $\mathrm{Pb}$ ) content in sewage water. It can be noticed from data presented in Fig. 8 that the highest concentrations of heavy metals $(\mathrm{Cd}$ and $\mathrm{Pb})$ were produced in root followed by shoot Such results agreed with those obtained by El-Naim and El- Houseini, (2002) they showed that sewage sludge caused lightly increase in the edible parts contents of heavy metals of corn and sunflower. Moreover, Abdel-Sabour and Rabie (2003) revealed that irrigation with different wastewater significantly increased the concentration of heavy metals $(\mathrm{Pb}$ and $\mathrm{Cd})$ in vegetable plants (Spinach, Rocket and Jew's mallow) especially the leafy species.

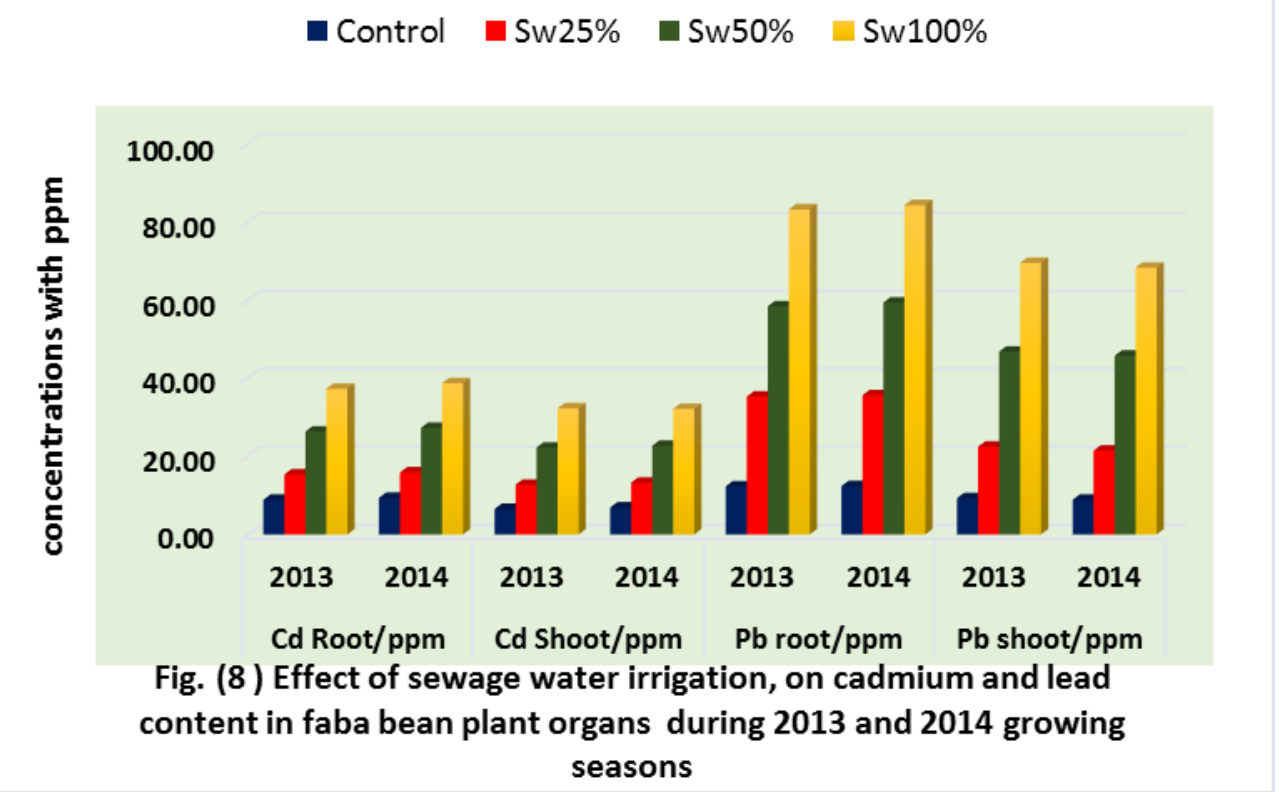

\subsubsection{Seeds nutrient elements, protein and total carbohydrates composition}

Fig. 8 -A showed that sewage water application at lower concentration $(25 \% \mathrm{SW})$ increase nitrogen, phosphorus and Potassium percentage in seeds of faba bean plant both seasons compared with control. On the other hand the highest application of sewage water $(100 \%$ SW) decrease nitrogen, phosphorus and
Potassium percentage in seeds of faba bean plant in both seasons. These results confirmed with Kiziloglu et al. (2007) who showed that wastewater irrigation treatment increased $\mathrm{N}$ contents of cauliflower and red cabbage plants. 
Table (8) and Fig. 8 -B showed that sewage water application at $25 \%$ significantly decreased Zinc and iron concentrations in seeds compared with control in both seasons. While sewage water at $50 \%$ and $100 \%$ led to a significant increase in Zinc and iron concentrations of seeds of faba bean plants compared with control in both seasons. The highest values of Zinc and iron concentrations obtained from using sewage water at $100 \%$. These results confirmed with Abdel-Sabour and Rabie (2003) revealed that irrigation with different wastewater significantly increased the concentration of heavy metals $(\mathrm{Zn})$ in vegetable plants (spinach, rocket and Jew's mallow) especially the leafy species. Badawy and ElMotaium (2003) found that the concentrations of $\mathrm{Zn}$, in tomato leaves and fruits increased with sewage sludge application rate.

Table (8) and Fig. $8-\mathrm{C}$ showed that Seeds content of heavy metals $(\mathrm{Cd}$ and $\mathrm{Pb})$ significant increase with increasing sewage water concentrations. This increasing in heavy metals content may be attributed to increasing of heavy metals $(\mathrm{Cd}$ and $\mathrm{Pb})$ content in sewage water.

Table (8) and Fig. 8 -D demonstrate that, sewage water application at $25 \%$ and $50 \%$ significantly increased protein and total carbohydrates in seed compared with control plant in both seasons. On the other hand sewage water at $100 \%$ concentration significantly decreased seed content of protein and total carbohydrates in both seasons compared with control.

Table 8. Effect of sewage water irrigation, on Seeds nutrient elements, protein and total carbohydrates composition during 2013 and 2014 growing seasons

\begin{tabular}{|c|c|c|c|c|c|c|c|c|c|c|c|c|}
\hline \multirow{3}{*}{$\begin{array}{c}\text { Water } \\
\text { irrigation }\end{array}$} & \multicolumn{12}{|c|}{ Seeds nutrient elements, protein and total carbohydrates composition } \\
\hline & \multicolumn{2}{|c|}{ Zn (ppm) } & \multicolumn{2}{|c|}{ Fe (ppm) } & \multicolumn{2}{|c|}{ Cd (ppm) } & \multicolumn{2}{|c|}{$\mathbf{P b}(\mathbf{p p m})$} & \multicolumn{2}{|c|}{ Protein \% } & \multicolumn{2}{|c|}{ Total Carbohydrates \% } \\
\hline & 2013 & 2014 & 2013 & 2014 & 2013 & 2014 & 2013 & 2014 & 2013 & 2014 & 2013 & 2014 \\
\hline control & $\overline{10.46}$ & 10.26 & 31.05 & 31.25 & 0.08 & 0.07 & 0.7 & 0.73 & 29.26 & 29.39 & 36.96 & 36.54 \\
\hline Sw25\% & 8.93 & 8.8 & 24.4 & 25.48 & 0.35 & 0.38 & 1.2 & 1.17 & 37.85 & 38.23 & 52.09 & 52.78 \\
\hline Sw50\% & 12.37 & 12.73 & 33.3 & 34.37 & 0.59 & 0.61 & 1.77 & 1.9 & 31.76 & 33.69 & 47.11 & 46.83 \\
\hline Sw100\% & 17.51 & 17.71 & 68.36 & 68.78 & 0.78 & 0.78 & 2.5 & 2.6 & 24.5 & 26.15 & 35.88 & 35.74 \\
\hline LSD0.05 & 0.36 & 0.27 & 0.31 & 0.41 & 0.04 & $\mathbf{0 . 0 3}$ & 0.08 & 0.11 & 1.24 & 1.30 & 0.96 & 0.67 \\
\hline
\end{tabular}

Fig. 8 (A, B, C and D)
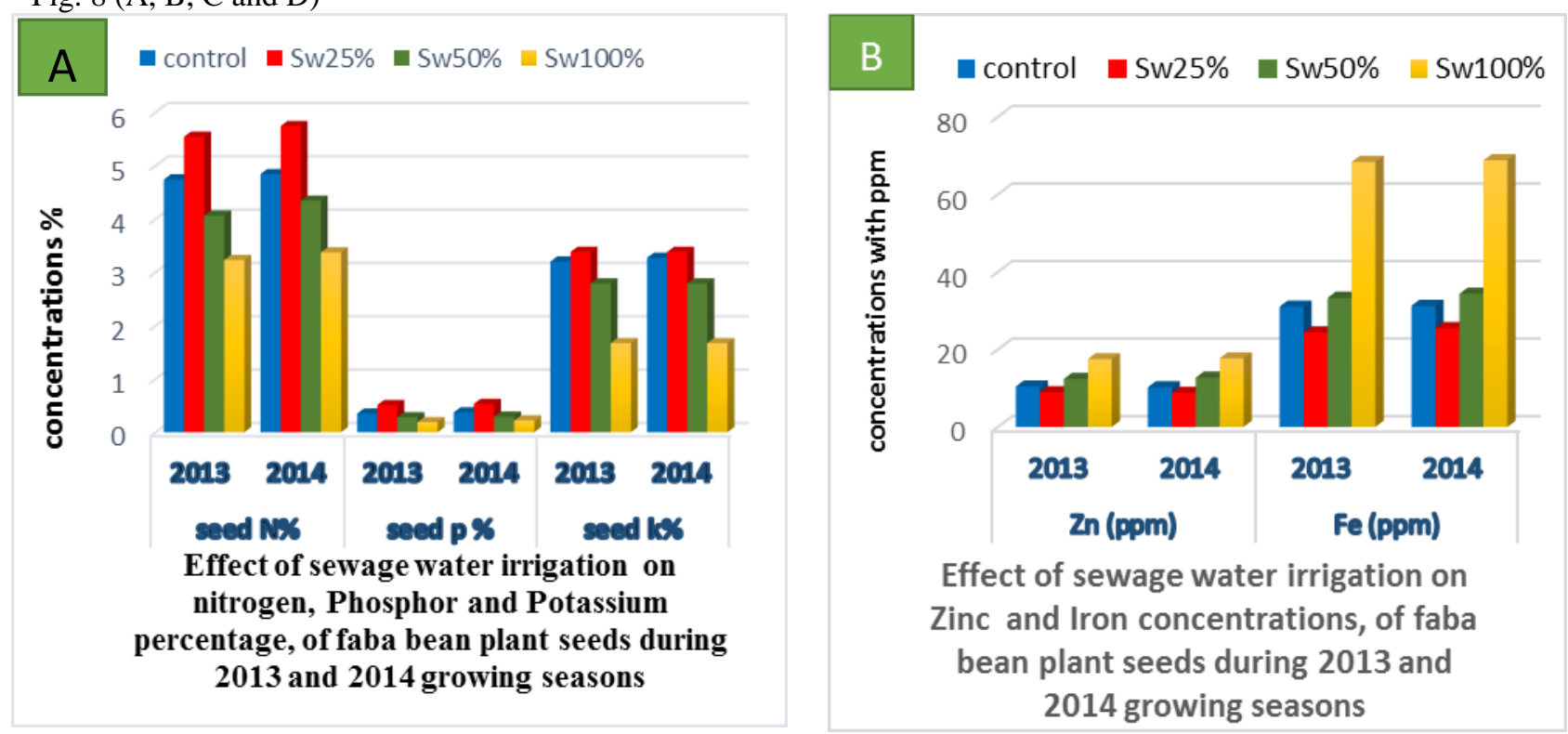


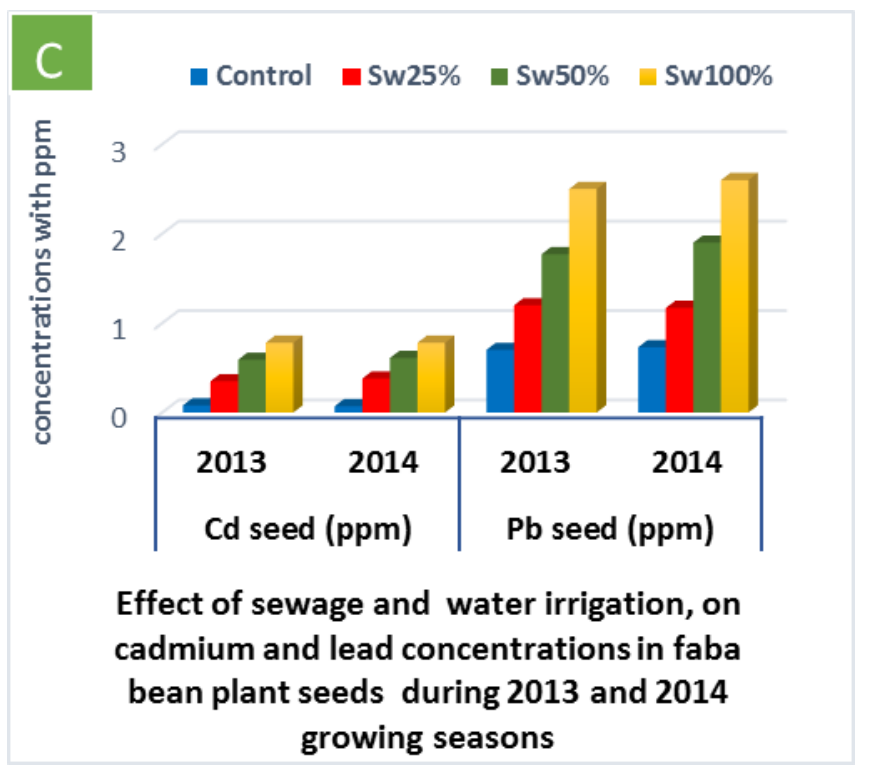

3.1. Anatomical studies

Fig. 9 and table (9) showed that all sewage water treatment showed decrease root anatomical traits such as root diameter, central cylinder diameter, and cortex thickness, whether these are parenchymatous tissues in the root cortex and/or xylem vessels, thereby resulting in a shrinkage of root diameter. It is clear from same data that application of sewage water at $100 \%$ gave the highest reduction in thickness of cortex tissue, and diameter of vascular cylinder. Remain parenchyma tissue in the cortex and pith or will develop into xylem vessels. The vascular system This may be due to a decrease in the elasticity of cell walls of the root Heavy

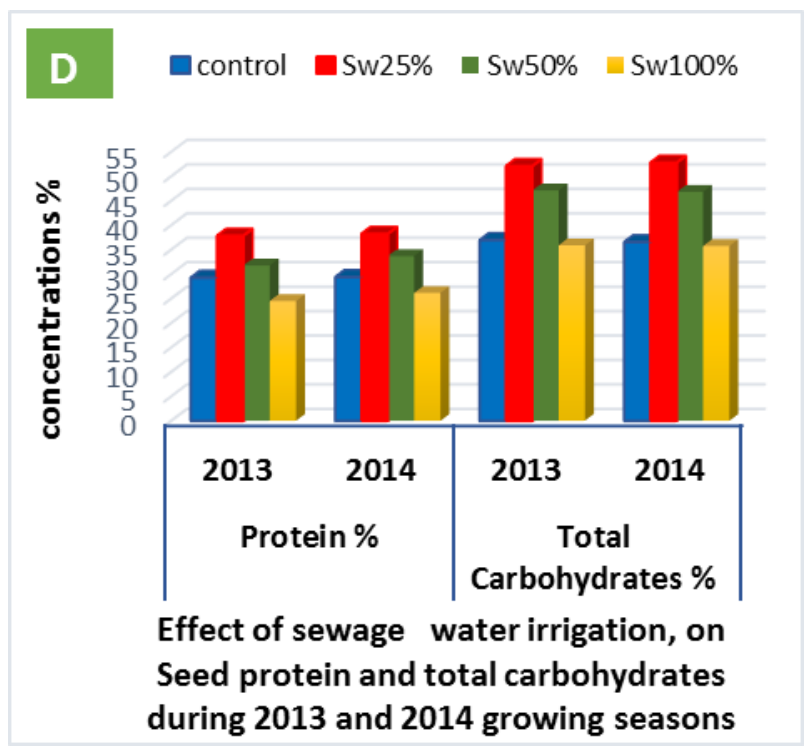

metal-induced reduction in the cell size includes all root tissue, whether these are parenchymatous tissues in the root cortex and/or xylem vessels, thereby resulting in a shrinkage of root diameter (Kasim 2006). A significant decrease in xylem vessels, in particular, metaxylem vessels may significantly limit the movement of water and mineral nutrients from root to aerial parts of the plant. (Gowayed and Almaghrabi 2013) also reported a reduction as a result of heavy metal stress in root anatomical traits such as root diameter, central cylinder diameter, and cortex thickness, cross section area of root and cross section area of central cylinder.

Table 9. Effect of sewage water irrigation, on on root cross-section

\begin{tabular}{ccccccc}
$\begin{array}{c}\text { Water } \\
\text { irrigation }\end{array}$ & $\begin{array}{c}\text { Root } \\
\text { diameter } \\
\mu \mathrm{m}\end{array}$ & $\begin{array}{c}\text { Vascular } \\
\text { diameter } \mu \mathrm{m}\end{array}$ & $\begin{array}{c}\text { Cortex } \\
\text { thickness } \\
\mu \mathrm{m}\end{array}$ & $\begin{array}{c}\text { Number of } \\
\text { rows cortex }\end{array}$ & $\begin{array}{c}\text { Pith } \\
\text { diameter } \\
\mu \mathrm{m}\end{array}$ & $\begin{array}{c}\text { Met xylem } \\
\text { vessels diameter } \\
(\boldsymbol{\mu})\end{array}$ \\
\hline Control & $\mathbf{2 4 3 3 . 3}$ & $\mathbf{1 1 8 3 . 3}$ & $\mathbf{6 8 3 . 3 3}$ & 11.6 & $\mathbf{2 0 . 0}$ & $\mathbf{6 5 . 0}$ \\
SW 25\% & $\mathbf{2 0 6 6 . 6}$ & $\mathbf{1 0 8 3 . 3}$ & $\mathbf{5 6 6 . 6 6}$ & $\mathbf{8 . 7}$ & $\mathbf{4 6 . 7}$ & $\mathbf{4 3 . 3}$ \\
SW 50\% & $\mathbf{1 8 7 0}$ & $\mathbf{9 1 6 . 6}$ & $\mathbf{4 6 8 . 3 3}$ & 7.3 & $\mathbf{1 0 6 . 7}$ & $\mathbf{3 8 . 3}$ \\
SW100\% & $\mathbf{1 6 5 0}$ & $\mathbf{7 0 3 . 3}$ & $\mathbf{4 0 0 . 0 0}$ & $\mathbf{6 . 7}$ & $\mathbf{1 7 0 . 0}$ & $\mathbf{3 3 . 3}$ \\
LSD0.05 & $\mathbf{2 8 . 0 3}$ & $\mathbf{1 7 . 6 2}$ & $\mathbf{7 . 9 8}$ & $\mathbf{1 . 5 8}$ & $\mathbf{1 6 . 7 7}$ & $\mathbf{1 2 . 3 1}$ \\
\hline
\end{tabular}



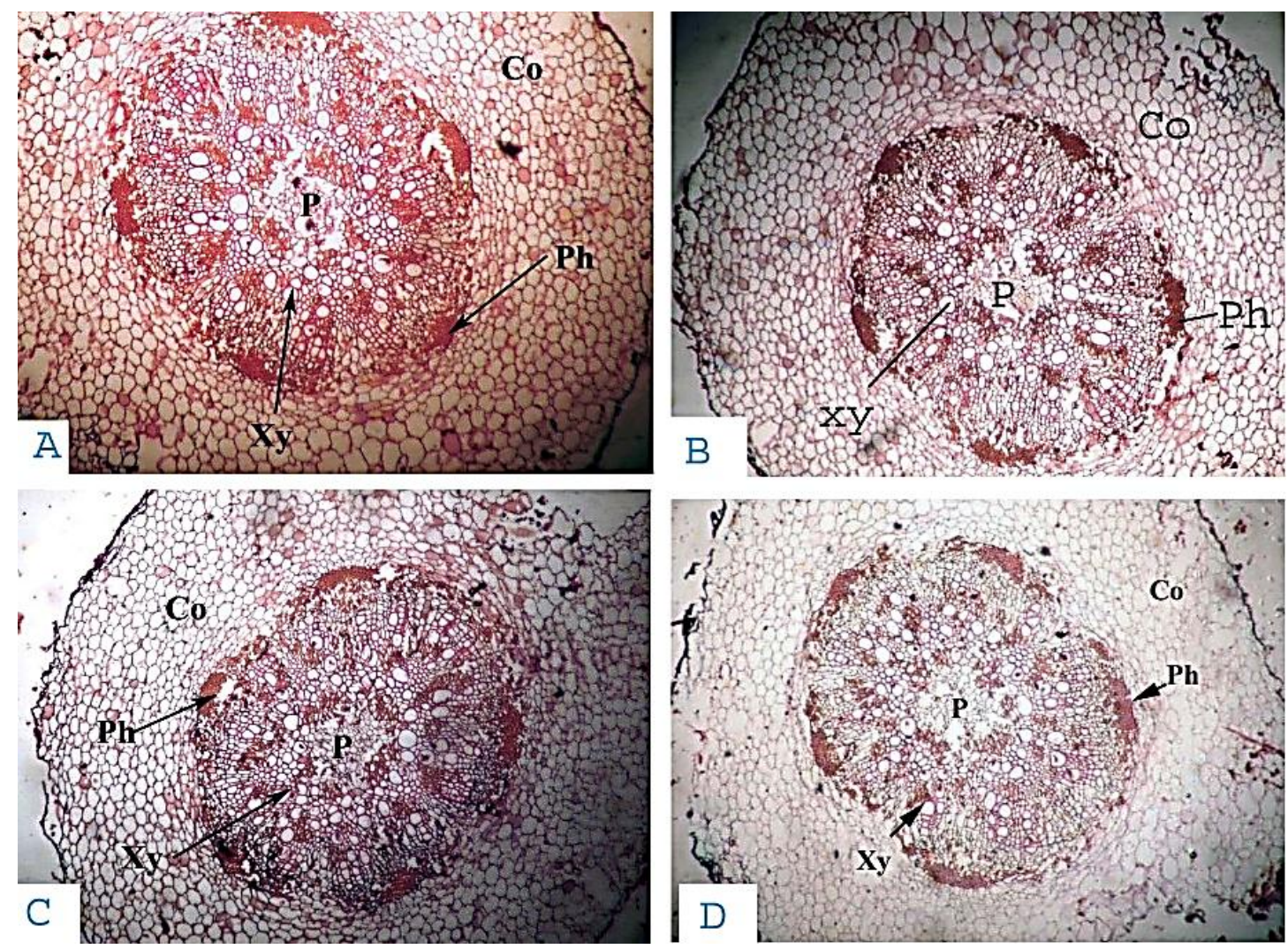

Fig. (9) Effect of sewage water irrigation, on on root cross-section diameter, cortex thickness, pith diameter, and xylem vessel diameter in root of faba bean (X160)

$$
\begin{array}{cc}
\text { Co }=\text { cortex } & \begin{array}{l}
\text { Xy }=\text { xylem, and } \\
\text { A- control }
\end{array} \\
\text { C- } 50 \% \mathrm{SW} & \text { pith } \mathrm{Ph}=\text { phloem } \\
\text { B- } 25 \% \mathrm{SW} \\
\mathrm{D}-100 \% \mathrm{SW}
\end{array}
$$

Fig. 10 and table (10) showed a decrease in stem diameter with an increase sewage water irrigation level compared with control. The application of sewage water at $25 \%$ gave the highest value of stem diameter, thickness of epidermal cells, thickness of cortex layer including both collenchyma and parenchyma tissues, No. of vascular bundles and thickness of xylem tissue as compared with concentrations of sewage water
$(100 \%)$. While the highest concentrations of sewage water (100\%) led to insignificant increase in all studied stem parameters. A number of studies reported that reduction of shoot elongation in the presence of $\mathrm{Cd}$ is due to reduction of photosynthesis. It has been reported

\begin{tabular}{|c|c|c|c|c|c|c|}
\hline $\begin{array}{c}\text { Water } \\
\text { irrigation }\end{array}$ & $\begin{array}{c}\text { Stem } \\
\operatorname{diameter}(\mu)\end{array}$ & $\begin{array}{c}\text { Thickens of } \\
\text { epidermal cell } \\
(\mu)\end{array}$ & $\begin{array}{c}\text { Thickness of } \\
\text { cortex layer } \\
(\mu)\end{array}$ & $\begin{array}{c}\text { Xylem } \\
\text { tissue }\end{array}$ & $\begin{array}{l}\text { Metaxylem } \\
\text { vessels } \\
\text { diameter }(\mu)\end{array}$ & $\begin{array}{c}\text { No.of } \\
\text { vascular } \\
\text { bundles }\end{array}$ \\
\hline Control & 3500 & 56.66 & 383.33 & 300 & 32 & 20 \\
\hline sw $25 \%$ & 2600 & 43.33 & 285 & 233.33 & 30 & 15 \\
\hline sw $50 \%$ & 2083.33 & 40 & 268.33 & 141.66 & 25 & 14 \\
\hline Sw100\% & 1858.33 & 35 & 235 & 141.66 & 26.33 & 13 \\
\hline LSD0.05 & 29.55 & 12.33 & 6.7 & 5.8 & 2.67 & 0.789 \\
\hline
\end{tabular}
that, heavy metals may cause anatomical changes in leaves and stems (Wan et al., 2011 and Soudeh and Zarinkamar 2012).

Table 10. Effect of sewage water irrigation, on stem cross-section of faba bean 

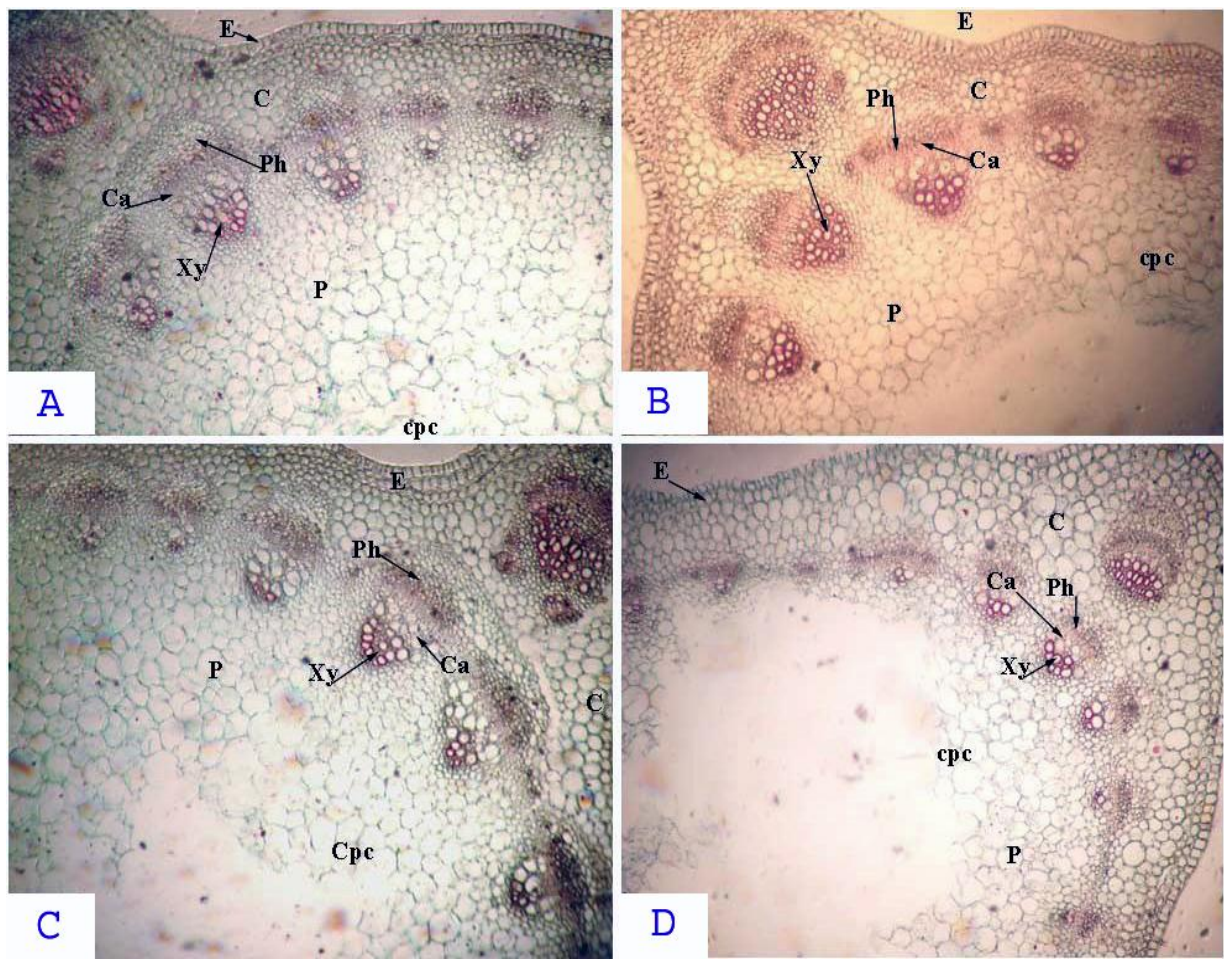

Fig. (10) Effect of sewage water irrigation, on stem cross-section of faba bean(X160) $\mathrm{C}=$ cortex $\mathrm{Xy}=$ xylem, $\mathrm{P}=$ pith, $\mathrm{Ca}=$ cambium and $\mathrm{Ph}=$ phloem

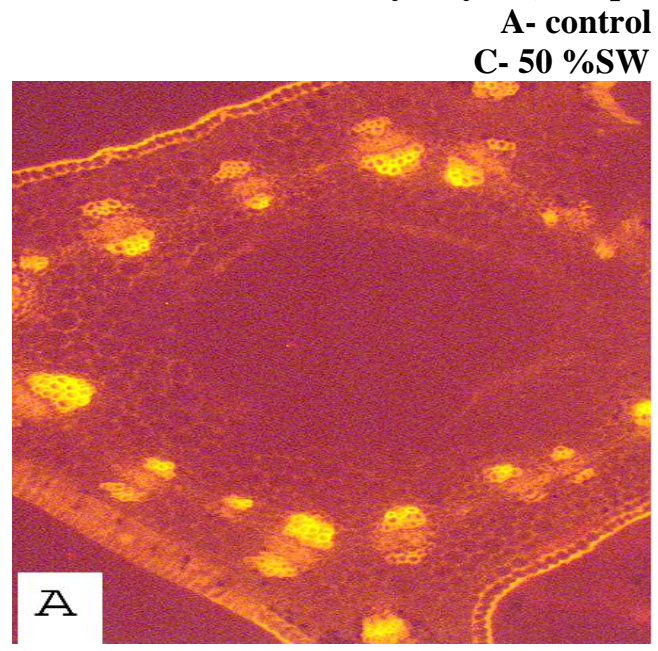

A- $100 \%$ SW

Fig. (11) Analysis of fluorescence revealed lignin deposit in the Epidermis cells that was observed in the treatment exposed to the highest level of sewage water the tracheary elements of the xylem and cortical parenchyma of stem exposed to higher concentrations of sewage water presented thicker walls than the control

Analysis of fluorescence revealed a lignin deposit on the walls of Epidermis cells in stem exposed to the treatment with sewage water at $100 \%$, absent in the control (Figure 11 A). Stem of plants cultivated under sewage water irrigation presented changes in size,

\section{B- $25 \% \mathrm{SW}$}

D- $100 \% \mathrm{SW}$

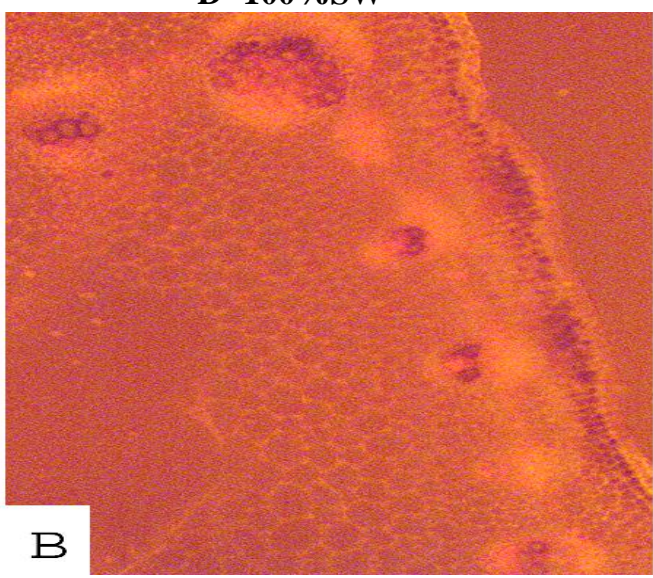

\section{B - control}

shape and arrangement of cortical parenchyma cells (Figure 11 A). Particularly, plants of the treatment with more concentrations had widened cell spaces in the cortex that were virtually always present where death of parenchyma cells was observed. Besides the cell degeneration induction, changes in cell shape and organization suggests a heavy metal interference in the root maturation rate, probably due to the ability of heavy metal disrupt the hormonal balance (Sandalio et al., 2001).

Data in table (11) showed that in the internal morphology the number of stomata/ $\mathrm{mm} 2$, length and 
width showed a significant decrease with all sewage water treatment compared with control. The limitations of stomata on photosynthesis are well-documented (Mediavilla et al. 2002). Therefore, reductions in stomatal dimensions and the number acquire greater physiological significance when coupled with reductions in leaflet area. Stomatal dimensions and stomatal frequency are clearly substantiated by the measured reductions of photosynthetic pigments (chl-a, chl-b)

Table 11. Effect of sewage water irrigation, on number of stomata and size of stomata guard cell of faba bean

\begin{tabular}{|c|c|c|c|}
\hline Water irrigation & \multirow{2}{*}{$\begin{array}{l}\text { Number of stomata } \\
\qquad \mathrm{mm}^{2}\end{array}$} & \multicolumn{2}{|c|}{ Size of guard } \\
\hline & & length & \\
\hline Control & 20.00 & 67.31 & \\
\hline Sw100\% & 14.00 & 61.51 & \\
\hline Sw25\% & 18.33 & 99.51 & \\
\hline Sw50\% & 16.67 & 60.40 & \\
\hline LSD0.05 & $\mathbf{0 . 7}$ & & 2.92 \\
\hline
\end{tabular}

Fig. 112- B abaxial epidermis of faba bean leaves showed slightly elongated cells irregular in shape with reduced size at the higher concentrations of sewage water treatment.

\section{References}

A.O.A.C. 1995. Association of Official Agricultural Chemists. Official methods of analysis 16 th ed Washington D.C., USA

Abd-Alla, H.M., Yan, F., and Schubert, S., 1999. Effects of sewage sludge application on nodulation, nitrogen fixation and plant growth of faba bean, soybean and lupin.J. Appl. Bot. 73, 69-75.

Abdel-Sabour, M.F. and Rabie F.H., 2003. Accumulation of heavy metals in vegetable plants grown in mostorod area. Egypt. J. Soil Sci., 43, (1). P: 63-76.

Asgari, K., P. Najafi, A. Soleymani and R. Larabi, 2007. Effects of treated municipal wastewater on growth parameters of corn in different irrigation conditions. J. Boil. Sci., 7: 1430-1435.

Aziz, o.; Manzar M. and Arif -Inam (1995). Suitability of petrochemical industry wastewater for irrigation. J. Environ. Sci. and Helth .Part A., Anvion. Sci\& Engineering. 30 (4): 735-751.

Badawy, S.H. and El-Motaium, R.A., (2003). Fate of some heavy metals in sandy soil amended with sewage sludge and their accumulation in plants. Egypt. J. Soil Sci. 43, (1), p: 1-17.
Bhati, M. and Singh G., (2003) Growth and mineral accumulation in Eucalyptus camaldulensis seedlings irrigated with mixed industrial effluents. Bioresource Technol., 88: 221-228.

Bouyoucos, G.J., 1965. Hydrometer method for making particle size analysis of soils. Agron. J., 54: 464-465.

Bray, E.A., Bailey-Serres, J. and Wereltilnyk, E.2000. Responses to abiotic stresses. pp: 1158- 1249. In: W. Gruissem (ed.). Biochemistry and Molecular Biology of Plants. American Society of Plant Physiologists.

Chapman, H.D. and P.F. Pratt, 1982. Method and of analysis of soil, plant and water. 2nd Ed. California: California University Agricultural Division, pp: 170.

Chaves, M.M. and Oliveira, M.M. 2004. Mechanisms underlying plant resilience to water deficits: prospects for water-saving agriculture. J. Exp. Bot. 55:365-384

Duc, G. 1997. Faba bean (Vicia faba L.). Field Crop Res. 53: 99-109

Gomaa, A.M., 1989. Biofertilizers and increasing of crop production. M. Sc. Thesis, Fac. Agric. Cairo. Univ. 
Ehiagbonare JE, Obayuwana S, Aborisade WT, and Asogwa I 2011. Effect of unspent and spent diesel fuel on two agricultural crop plants: Arachis hypogea and Zea mays. Sci Res Essays 6:22962301.

Eid, M.A. and Shereif, M.M. 1996. Effect of Wastewater Irrigation on Growth and Mineral contents of Certain Crops (greenhouse Conditions). Egypt.J.soil.Sci. 36, (1-4), pp. 109-118

El-Naim, M. Abd and El-Houseini, M. 2002. Environmental aspects of sewage sludge application in Egypt." 17 WCSS, 14-21 August,th No. 50, 2002, Thailand.

El-Okkiah, Samira (2010). Control the physiological stress resulted from environmental pollutants on Vicia Faba using foliar spray with certain growth regulators Ph.D Thesis, Kafrelsheikh University Egypt

FAO/WHO, 2004. Summary of Evaluations Performed by the Joint FAO/WHO Expert Committee on Food Additives (JECFA 1956-2003), (First Through Sixty First Meetings). ILSI Press International Life Sciences Institute.

Gasco, G. and Lobo, M.C., 2007. Composition of Spanish sewage sludge and effects on treated soil and olive trees. Waste Manage, 27: 1494-1500.

Gowayed, Salah M. H.; Almaghrabi Omar. A. 2013.Effect Of Copper and Cadmium on Germination and Anatomical Structure of Leaf and Root Seedling in Maize (Zea mays L) Australian Journal of Basic \& Australian Journal of Basic and Applied Sciences, 7(1): 548-555

Hati, K.M., Biswas, A.K. Bandyopadhyay, K.K. and Misra, A.K. 2007. Soil properties and crop yields on a vertisol in India with application of distillery effluent. Soil Till. Res., 92: 60-68.

Jadoon, Khan. Bashir. Irum., Ali, Shafaqat., Jadoon, Khan. Bashir. Qurratulain., Shakoor, Bilal. Muahammad.,Bharwana, Aslam. Saima, and Farooq, Ahsan. Muhammad. 2013. Effects of irrigation with wastewater from different industries on vegetables grown in vicinity of Faisalabad, Pakistan; A review. International Research Journal of Plant Science, 4(6): 144-148.

Jackson, M.L., 1973. Soil Chemical Analysis. 1st Edn., Prentice Hall of India Pvt. Ltd., New Delhi, India.

John, M.K., 1970. Colorimetric determination of phosphorus in soil and plant materials with ascorbic acid. Soil Science, 109: 214-220.

Kasim, W.A., 2006. Changes Induced by copper and cadmium stress in the anatomy and grain yield of sorghum bicolor (L.) Moench. Iin. J. of Agri. \& Bio., 1: 123-128.

Kiziloglu, F.M. Turan, M. U. Sahin, Angin I, Anapali, O. and Okuroglu, M. 2007. Effects of wastewater irrigation on soil and cabbage-plant (Brassica olerecea var. capitate cv. yalova-1) chemical properties, J. Plant Nutr. Soil Sci. 170, pp. 166-172

Küpper H., Šetlík, I., Küpper, F., Spiller M, Prášil O 2002. Heavy metal-induced inhibition of photosynthesis: targets of in vivo heavy metal chlorophyll formation. J Phycol 38: 429-441.

Lux, A., Morita, S., Abe, J., Ito K. 2005. Improved method for clearing and staining free-hand sections and whole-mount samples. Annals of Botany 96, 989-996.

Majid, N.M., Islam M.M., and Riasmi, Y. 2012 Heavy metal uptake and translocation by Jatropha curcas L. in sawdust sludge contaminated soils. Aust J Crop Sci. 6: 891-898

Mead, P \& P. Griffin. 1998. Escherichia coli O157: H7. Lancet 352: 1207-1212.

Mediavilla S, Santiago H and Escudero A. 2002 Stomatal and mesophyll limitations to photosynthesis in one evergreen and one deciduous Mediterranean oak species. Photosynthetica 40(4): 553-559.

Moran, R., 1982. Formulae for determination of chlorophyllous pigments extracted with N,Ndimethylformamide. Plant Physiol. 69, 1376-1381

Narain, Kamini., Bhat, Muzamil. Mohd., Abhilash P.C. and Yunus, Mohammad. 2012. Impact of distillery effluent on seedling growth and pigment concentration of cicer arietinum L., Journal of Environmental Research and Development, 6. (3) A.

Panou-Filotheou H. and Bosabalidis A. M. 2004 Root structural aspects associated with copper toxicity in oregano (Origanum vulgare subsp. hirtum). Plant Sci. 166, 1497-1504

Pearson, D. 1976. The chemical analysis of foods 7 th Ed. Churchill, London, U.K.

Purakayastha T.J., and Chhonkar P.K. 2010 Phytoremediation of heavy metal contaminated soils. In: Sherameti I, Varma A (eds) Soil Heavy Metals. Soil Biology, vol 19. Springer, Verlag Berlin Heidelberg, pp 389-430

Radoglou, K. M. and Jarvis, P. G. 1992. Effects of $\mathrm{CO}_{2}$ enrichment and nutrient supply on growth morphology and anatomy of Phaseolus vulgaris L. seedlings. Annals of Botany, 70(3), 245-256

Raia, Shankar. Hari, and Khan, Kafeel. Khalid. 2010. Effect of industrial effluent on seed germination and seedling growth of Hordeum vulgare $\mathrm{L}$. (Barley). Indian J. Sci. Res, 1 (2), 87-89.

Ruzin SE.; 1999, Plant microtechnique and microscopy. Oxford: Oxford University Press.

Sandalio, L.M., H.C. Dalurzo, M. Gomes, M. RomeroPuertas, L.A. del Rio, 2001. Cadmium- induced changes in the growth and oxidative metabolism of pea plants. J. Exp. Bot., 52, 2115-2126. 
Saravanamoorthy, M.D. and Ranjitha Kumari, B.D. 2007. Effect of textile waste water on morphophysiology and yield on two varieties of peanut (Arachis hypogaea L.). Journal of Agricultural Technology; 3(2): 335-343.

Simon, T., 2000. The effect of nickel and arsenic on the occurrence and symbiotic abilities of native rhizobia. Rostlina Vyroba. 46, 63-68.

Snedecor G.W, Cochran W.G 1967 Statistical Methods, ed. 6. Ames, Iowa, the Iowa State University Press

Tawfik, K.M., 2008. A Monitory Field Study at El Saaf - Helwan Faba bean Farms Irrigated by Industrial Waste Water and Polluted Water with Sewage J. Appl. Sci. Res., 4(5): 492-499
Vaculík, M., C. Konlechner, I. Langer, W. Adlassnig, M. Puschenreiter, A. Lux and M.T. Hauser, 2012. Root anatomy and element distribution vary between two Salix caprea isolates with different $\mathrm{Cd}$ accumulation capacities. Environ. Pollution, 163117-126.

Yemm E.W., and Willis A.J. 1954. The estimation of carbohydrates in plant extracts by anthrone. Biochem. J. 57, 508-514

Yadav, R.K., Goyal, B. Sharma, R.K. Dubey S.K. and Minhas, P.S. 2002. Post-irrigation impact of domestic sewage effluent on composition of soils, crops and ground water: A case study. Environ. Int., 28: 481-486 


\title{
اثر سميه مياه الصرف الصحى على صفات النمو والمحصول والصفات الفسيولوجيه والبيوكيميائية والتشريحية للفول البلدى
}

\author{
سميره احمد فؤاد حسن العكيه \\ قسم النبات الزراعى - كليه الزراعه- جامعه كفرالثيخ
}

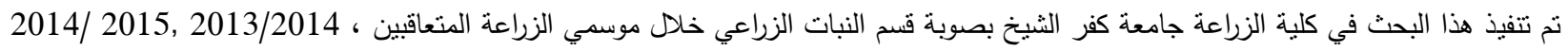
وكان الهدف الرئيسي من هذا البحث هو دراسه اثر سميه مياه الصرف الصحى على الصفات النمو والمحصول والصفات الفسيولوجيه والبيوكيميائية

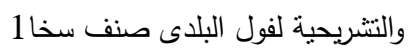
ويمكن تلخيص النتائج المتحصل عليها في الاتي:

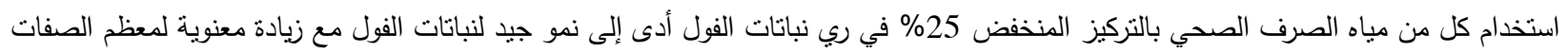

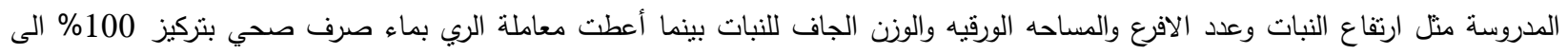

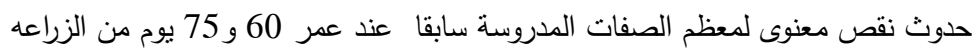

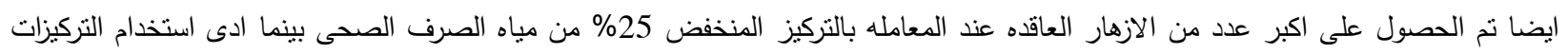
المرتفعه الى نقص هذه الصفه. ادت المعامله ايضا بالتركيز المنذفض الفى لفئه زياده عدد القرون ووزن ال100 بذره والى زياده محصول البذره بالنسبه للنبات بينما ادت المعامله بالتركيز

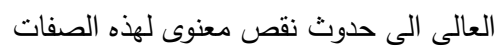
وبالنسبه للصفات الفسيولوجيه ادت المعامله بالتركيز المنخفض 25\% الفئ زياده تركيز الورقه من صبغات الكنات الكلوروفيل (أ ، ب والكلى) والى زياده

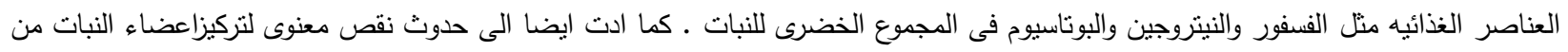
العناصر الثقيله بينما أعطت معاملة الري بماء صرف صحي بتركيز 100\% اللى حدوث نقص معنوى فى تركيز الكلورفيل والعناصر الغذائيه بينما ادت الى حدوث زياده معنويه فى تركيز النبات من العناصر الثقله.

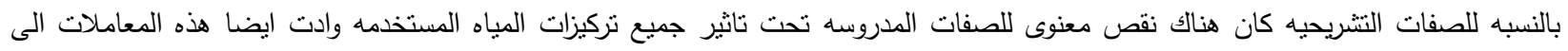
خفض عدد الثغور · 